NBER WORKING PAPER SERIES

ARE TEACHER ABSENCES WORTH WORRYING ABOUT IN THE U.S.?

Charles T. Clotfelter

Helen F. Ladd

Jacob L. Vigdor

Working Paper 13648

http://www.nber.org/papers/w13648

\author{
NATIONAL BUREAU OF ECONOMIC RESEARCH \\ 1050 Massachusetts Avenue \\ Cambridge, MA 02138 \\ November 2007
}

Clotfelter - Corresponding author: Box 90245 Duke University, Durham, NC 27708, charles.clotfelter@duke.edu; phone 919-613-7361. The authors wish to thank Robert Malme, L. Patten Priestley, and Marco Hernandez for research assistance; Ronald Ehrenberg, Dave Marcotte, and Richard Murnane for helpful comments; the North Carolina Education Research Data Center for assistance obtaining and using data for North Carolina public schools; and the Spencer Foundation and the National Center for Analysis of Longitudinal Data in Education Research (CALDER) for financial support. The views expressed are those of the authors and do not necessarily reflect those of any institution.

(C) 2007 by Charles T. Clotfelter, Helen F. Ladd, and Jacob L. Vigdor. All rights reserved. Short sections of text, not to exceed two paragraphs, may be quoted without explicit permission provided that full credit, including $\odot$ notice, is given to the source. 
Are Teacher Absences Worth Worrying About in the U.S.?

Charles T. Clotfelter, Helen F. Ladd, and Jacob L. Vigdor

NBER Working Paper No. 13648

November 2007

JEL No. I21

\begin{abstract}
$\underline{\text { ABSTRACT }}$
Using detailed data from North Carolina, we examine the frequency, incidence, and consequences of teacher absences in public schools, as well as the impact of an absence disincentive policy. The incidence of teacher absences is regressive: schools in the poorest quartile averaged almost one extra sick day per teacher than schools in the highest income quartile, and schools with persistently high rates of teacher absence were much more likely to serve low-income than high-income students. In regression models incorporating teacher fixed effects, absences are associated with lower student achievement in elementary grades. Finally, we present evidence that the demand for discretionary absences is price-elastic. Our estimates suggest that a policy intervention that simultaneously raised teacher base salaries and broadened financial penalties for absences could both raise teachers' expected income and lower districts' expected costs.
\end{abstract}

Charles T. Clotfelter

Sanford Institute of Public Policy

Box 90245 Duke University

Durham, NC 27708

and NBER

charles.clotfelter@duke.edu

Helen F. Ladd

Sanford Institute of Public Policy

Box 90245 Duke University

Durham, NC 27708

hladd@duke.edu
Jacob L. Vigdor

Terry Sanford Institute of Public Policy

Box 90312 Duke University

Durham, NC 27708

and NBER

jacob.vigdor@duke.edu 


\title{
Are Teacher Absences Worth Worrying About in the U.S.?
}

\author{
Charles T. Clotfelter, Helen F. Ladd and Jacob L. Vigdor
}

Duke University

\section{Introduction}

Whatever the importance of strong training, classroom experience, or advanced pedagogical methods for the scholastic development of students, these factors can have scant effect on a day a teacher is absent from school. Teacher absences are an endemic problem in developing countries (Banerjee and Duflo 2006; Chaudhury et al. 2006). Baseline teacher absence rates in the range of 20 to 44 percent have been reported in studies of policy interventions in Kenya and India (Glewwe, Ilias and Kremer 2003; Duflo and Hanna 2005). Interventions designed to reduce teacher absence, or improve teacher performance generally, have met with mixed success in these settings (Banerjee and Duflo 2006).

The rate of teacher absence in the United States is much smaller than in these developing countries. Previous studies suggest absence rates for teachers in the U.S. on the order of $5 \%$, or about 9 days per 180 -day working year. ${ }^{1}$ Perhaps for this reason, there exists surprisingly little research on teacher absences in the United States. Compared to workers in other occupations, however, American school teachers appear to have relatively high rates of absence. By comparison, ostensibly similar rates of absenteeism due to sickness average less than $3 \%$ in the

\footnotetext{
${ }^{1}$ Ehrenberg etal. (1991), who conducted a survey of 381 school districts in New York state in the mid1980 s, found that teachers took an average of 8.9 days of leave a year. Podgursky (2003) cites a study of New York City schools in 2000/01 showing an average of 11.3 days a year and a U.S. Department of Education survey concluding that $5.2 \%$ of teachers were absent on any given day. Focusing only on sick leave, Bradley, Green and Leeves (2005, Table 1) report rates for Queensland, Australia of about 3\% and a similar rate based on another study in the U.K.
} 
U.S. workforce as a whole. ${ }^{2}$ This introduces the possibility that public education-specific policies have contributed to the elevated absence rate, and that policies could be used to reduce it. ${ }^{3}$ Potential social gains from reduced absenteeism include improved student discipline and achievement, and reduced expenditures on substitute teachers. ${ }^{4}$ Previous literature provides conflicting evidence on whether teacher absences are consequential for student achievement in America, where certified substitute teachers are widespread (Ehrenberg et al. 1991; Miller, Murnane and Willet 2006, 2007). Absenteeism may also have a regressive impact, in which case interventions to reduce it could promote equity as well as efficiency. ${ }^{5}$

This paper aims to address the questions of frequency, incidence, and effect, as well as the potential impact of leave policy, using data on public schools in North Carolina. We show that the pattern of absence-taking across schools in North Carolina has a disproportionate impact on low-income students. Ranking schools by the fraction of students receiving free or

2 Measured as a percentage of hours missed due to illness, maternity or paternity leave, or child care or other family obligations, the rates of absence in 2005 were $2.3 \%$ in the public sector and $1.7 \%$ in the private sector. In two similar occupations, it was $2.4 \%$ in community and social services and $2.7 \%$ in healthcare support (U.S. Bureau of Labor Statistics, 2006, Table 47).

${ }^{3}$ In addition to the generosity of leave policies, explanations given for the higher absenteeism of teachers include the high rate of infectious illnesses carried by students, the stress of the job, and the expectation that teachers will stay out of school to care for their own children. Such expectations and leave policies are consistent with the notion that teaching as an occupation has traditionally been made to suit working mothers, with short work days and summers off to accommodate the demands of child-rearing (Podgursky 2003).

${ }^{4}$ One estimate of the cost of substitutes due to excessive teacher absences is on the order of $0.5 \%$ of total per pupil expenditures (Roza 2007, p. 5).

${ }^{5}$ One of the rare stories that did touch on teacher absences, published in the Chicago Tribune, illustrates some of the issues lurking be neath the surface. Based on analysis of several years of $\mathrm{d}$ ata for the Chicago Public Schools, the Tribune reported chronic ab senteeism concentrated among so me teache rs in a subset of the district's schools. In 22 elementary schools, most of which served poor and minority students, per teacher absences averaged more than 20 days a year - a rate lower than that observed in developing countries, but quite substantial in a local context. In these schools, substitutes attempted to do little teaching, and discipline deteriorated (Dell'Angela and Little 2006). 
reduced-price lunch, teachers in the lowest quartile average almost one extra sick day per school year relative to teachers in the highest quartile. We also document that elementary students perform worse on standardized tests when they are assigned to teachers who take more absences. This relationship persists in models that incorporate teacher fixed effects. This finding corroborates the work of Miller, Murnane and Willet (2006, 2007). The estimated magnitude of the achievement effects is small, but aggregated across all students in a classroom they imply a non-negligible impact of absences on aggregate achievement.

Our study of the potential impact of leave policy on absences follows several existing studies on the subject. Ehrenberg et al. (1991)'s detailed analysis of teacher contracts for a large sample of New York school districts revealed that certain provisions were associated with higher usage of leave. ${ }^{6}$ Currently some districts in the U.S. offer bonuses for teachers who take a minimal number of absences; one district raffled off a new car among all teachers with perfect attendance. At the school level, some schools distribute to teachers at the end of the year any unused funds earmarked for substitute teachers. ${ }^{7}$ A randomized evaluation of a comparable bonus program for teacher attendance in India found that the teacher absence rate was halved in treatment schools (Duflo and Hana 2005). In addition, administrative rules covering teach

\footnotetext{
${ }^{6}$ These provisions included larger than average numbers of leave days allowed overall, larger numbers of days for bereavement leave, the presence of "sick leave banks," whereby teachers may borrow leave days not used by other teachers, and smaller numbers of contractually-specified professional leave. The authors also found that policies specifying the "buyback" of unused sick days - in cash or in the form of additional retirement benefits appeare d to influence the use of sick leave, with more generous buyback rates associated with fewer abse nces.

${ }^{7}$ For examples of some current policies regarding teacher absences, see Tawnell D. Hobbs, "DISD Hopes to Cut Daily Average of 678 Teachers Missing School," Dallas Morning News, September 24, 2002; Pat Kossan, "School Districts, Students Paying Price for Teacher Absences," The Arizo na Rep ublic, January 27, 2006; and Kristen A. Graham, “Teachers are Truant, Too, Reform Commission Says," Philadelphia Inquirer, December 7 , 2006 .
} 
reporting of absences have also been associated with differential rates of teacher absenteeism (Imants and Van Zoelen 1995). ${ }^{8}$

We evaluate the impact of a North Carolina policy that permits teachers to continue taking sick days once they have exhausted their supply of "free" days, at the cost of $\$ 50$ per day. The dependence of available sick days on the duration of a teacher's employment history and the number of sick days taken in prior years generates idiosyncratic variation in the point at which teachers face a price increase. Our estimates, derived from a modified form of survival analysis, indicate that the likelihood of taking an additional sick day, on the margin, is significantly lower when the cost is $\$ 50$ rather than zero. Back-of-the envelope calculations suggest that applying the $\$ 50$ penalty to all sick days starting with the first would reduce the average number of sick days taken by slightly more than 1 , or about $15 \%$. Given the savings that would result from cutting back on the use of substitute teachers, districts could raise base salaries sufficiently to increase teachers' expected income while still realizing cost savings.

The second section describes the data used in the present study and summarizes broad patterns in them, the third analyzes correlates of absenteeism, the fourth focuses on the distribution of teacher absence across schools, the fifth section examines the effect of teacher absence on student achievement, and the sixth evaluates the impact of financial penalties on absence-taking. The paper ends with a brief conclusion.

\section{Data}

Our data on teacher absences were provided by the North Carolina Department of Public

\footnotetext{
${ }^{8}$ For a number of references to studies of practices designed to reduce teacher absences, see also Miller, Murnane and Willett (2007).
} 
Instruction, the central state agency that collects uniform administrative data from all of the state's school districts. ${ }^{9}$ These administrative data cover the years 1994/95 to 2003/04, and we were able to link them to other administrative records on teachers by means of identifying numbers, encrypted so as to preserve confidentiality, supplied by the North Carolina Education Research Data Center. For virtually all teachers, the data set gives the number of days absent, by pay period and reason, and for most purposes we aggregate these data into annual totals for each teacher by year.

As is common in public school districts across the country, teachers in North Carolina are permitted to take a limited number of days off from work for sickness without losing pay or benefits, and these may include days when a child is sick or a doctor visit is scheduled. In addition, teachers may take off days for other reasons, with full or partial pay, without losing other employee benefits. Although the rules covering such absences are both copious and complicated, it is worth highlighting a few that apply to the most important types of absences sick leave and vacation leave.

Sick leave is credited to teachers in North Carolina at a flat rate of one day per month of work. Significantly for our study of teacher absence, this sick leave can accumulate in a teacher's account indefinitely and without limit, potentially giving some experienced teachers the ability to take very long spells of sick leave if necessary, without losing either their teaching position or their employee benefits. But another provision means there are real costs to using this leave: at the time of a teacher's retirement, any unused sick leave is converted to additional service credit

\footnotetext{
${ }^{9}$ Over the period covered by our data, the number of school districts in the state was reduced, through consolidation, from 119 to 117 . Throughout, the con solidated district definitions are used to classify data by district.
} 
and thus higher pension benefits in the state's defined-benefit system. A teacher who has exhausted her store of sick leave can take as many as 20 additional days of extended sick leave, but subject to a $\$ 50$ reduction in salary per day.

A second category of absence, which we label personal leave, covers voluntary absences other than sick leave. A day of leave in this category entails a deduction in pay, either $\$ 50$ or a full day's pay. ${ }^{10} \mathrm{~A}$ teacher who is absent due to illness but who has run out of accumulated sick leave and extended sick leave would be forced to use a type of leave in this category.

The third category is vacation (or annual) leave. Unlike sick leave and personal leave, which are by their nature usually unexpected and often disruptive to classroom instruction, vacation leave by design typically entails little disruption of classroom routines. Most days taken in this category are in fact mandated to coincide with school vacation days, and teachers are not allowed to take other days offas vacation days without a principal's permission. During their first two years of service, teachers are credited with exactly the number of days of vacation leave during the school year that they earn (10), thus leaving no additional days to use. After those first two years, teachers earn more than this minimum, at rates that rise with experience. ${ }^{11}$ Combined with the ability to accumulate sick leave indefinitely, this rising rate for vacation leave means being absent from school is generally easier for teachers as they gain more years of experience. Consequently, as we show below, average absence rates due to sickness and vacation tend to rise

\footnotetext{
${ }^{10}$ One form of what we generically label here as personal leave has the official name of personal leave, which accumulates at a rate of 0.2 days per month of work. This form is subject to the $\$ 50$ reduction in salary per day.

${ }^{11}$ The rate of accumulation for vacation leave rises fro $\mathrm{m} 1.15$ to 2.15 per month, the to $\mathrm{p}$ rate app lying to teachers with 20 or more years of experience. A maximum of 30 days of vacation leave may be carried forward from one year to the next, with the ex cess converted to sick leave.
} 
with experience. The only significant remaining category of leave is administratively mandated leave, usually for training and rarely held at a time that conflicts with classroom instruction.

Table 1 summarizes by category the main categories of leave taken by North Carolina teachers between 1994/95 and 2003/04. For the period, sick leave averaged 7.1 days per teacher, for a rate of about $3.9 \%$ based on a 180-day school year. Adding in personal leave, which averaged about 0.9 over the period, yields a slightly higher average rate of roughly $4.4 \%$, a rate that is in the same ball park as the $5 \%$ suggested in the few previous studies of teacher absences. ${ }^{12}$ Because they are usually unplanned-for, absences in the sick leave and personal leave categories are of paramount significance for the functioning of schools, and it is for this reason that we focus on them in the analysis in succeeding sections of the paper.

Under annual vacation leave, Table 1 reveals a fairly steady decline, from about 13 to about 10 over the period. Based on our conversations with school administrators, we believe this decline is largely an artifact of differing and changing administrative practices. Since the first 10 days of vacation leave correspond to mandatory school holidays, the amount charged to a fulltime teacher should never be less than 10, and indeed for most districts the average number of vacation leave days is well above 10. But for reasons not entirely clear to administrators in the affected districts or in the state education department, the reported numbers for some districts are much lower, in some cases covering only the excess vacation days above $10 .{ }^{13}$ For this reason,

\footnotetext{
${ }^{12}$ See footnote 3 above.

${ }^{13}$ Conversations with payro 11 and finance personnel in a number of districts and in the Department of Public Instruction uncovered various explanations for large jumps in reported vacation leave, including the adoption of new software, relate d changes in record-keeping, includ ing keeping parallel records over a period, lead ing to duplica te leave records, an agreement to compensate teachers with annual vacation leave in return for working at school athletic events, and the practice in a few districts of recording only days of an nual leave ab ove the 10 mandated days. These practices all appeared to be consistent with state policy, although they resulted in reported numbers of annual
} 
our statistical analysis involving vacation leave in succeeding sections examines variations only among teachers within the same district in the same year, thus allowing for practices in this regard to differ across districts as well as to change over time within each district. The last category of leave shown in the table, administrative leave, shows little variation over time, although it does differ across districts. ${ }^{14}$

As described above, the rules for accumulating leave explicitly favor more experienced teachers. Not only can teachers carry forward some vacation leave and all sick leave, the rate at which teachers earn vacation leave increases with experience. The actual usage of leave reflects these factors, as illustrated by the distribution of leave by experience level, shown in Figure 1 for the 2000/01 school year. Novice teachers have the lowest average usage of sick leave, at 4.8 days a year, compared to over 8 days a year for teachers with 5 to 10 years of experience. Vacation leave also tends to rise with experience, at least up to the last experience group. Excepting the most experienced teachers, both personal leave and administrative leave are essentially constant across the experience groups. To summarize, the most prominent regularity with respect to experience is the markedly lower rate of sick leave for inexperienced teachers.

At the individual level, absence rates differ widely across the teacher work force, and they

vacation leave days apparently inconsistent with state policy. Nonetheless, the extent to which otherwise similar districts differed in their average annual leave amounts could not be fully explained by any official.

${ }^{14}$ For a detailed list of all leave categories and their frequency in one year, see Appendix Table A1. Although the data available to us are very rich, we had to make a few adjustments to deal with several imperfections in the administrative records. First, records of absen ces for some teachers in so me years we re missing. We drop these teacher-year observations. For the years 1994/95 to 2000/01, these observations accounted for fewer than $1.5 \%$ of the total, but the percentage of missing teachers rises to $3.4 \%, 10.1 \%$, and $10.9 \%$ in the years $2001 / 02$ to $2003 / 04$. Second, we dropped the few observations with negative days of total leave or sick plus personal leave (most likely reflecting adjustments to a previous year's record) and those showing more than 150 days. Because they affected such small numbers of teachers, none of these adjustmen ts made any appreciable difference in results. 
differ as well across schools and districts. To give an indication of their variation at the individual level, Figures 2 and 3 present histograms for days of absence per year for North Carolina public school teachers over the years 1994/95 to 2003/04. Figure 2, which shows the distribution of absences for sick plus personal leave, reveals that the modal number of days of sick plus personal leave over the period was zero. The median was 6 , and the mean was 8 . A very small number of teachers accounted for a disproportionate share of the total days taken: the $10 \%$ of teachers showing the most days of sick plus personal leave accounted for a third of all teacheryear observations.

The frequency distribution for vacation leave, shown in Figure 3, reveals two peaks, one at 6 days and the other at 10, a result of the apparent anomaly in the reporting or recording of annual leave noted in the previous section. The higher peak reflects the standard practice whereby all teachers are automatically charged with the 10 days per year corresponding to school holidays, with any excess discretionary annual leave days added on top. The lower peak reflects the sizable number of districts which, at least in some years, averaged significantly fewer than the standard 10 days per teacher.

Absence rates varied markedly across schools and, to a lesser extent, across school districts. Figure 4 illustrates the variation across districts by showing the average sick plus personal absences, ranked from lowest to highest in the state. Whereas 15 districts had fewer than 8 absences per teacher, seven districts at the top had more than 11 per teacher. It is worth noting that such rankings by district tend to be fairly stable over time. To illustrate, Figure 5 shows the scatter plot of average absence rates by district in school years three years apart. The high intertemporal correlation suggested by the figure is also indicated by a correlation coefficient of 
$.653 .{ }^{15}$ Needless to say, such high-absence districts, as well as problematic schools within districts, should be a source of real concern if teacher absence harms student achievement.

\section{Which Teachers are Absent Most Often?}

To understand what kinds of teachers tend to be absent most often, we estimated OLS regressions with absences of different types as the dependent variable. We pooled records over the seven school years from 1994/95 to 2003/04. Including all classroom teachers working at least 10 months yields a sample of more than 492,000 observations. Covariates used as explanatory variables include the teacher's gender, race, age, and years of experience, information on the teacher's education and teacher credentials, and information on the teacher's school and district. Because of the strong indication, noted above, that the conventions for recording vacation leave were not constant across districts or over time, regressions that included such leave were estimated with district-by-year fixed effects. For the sake of comparison, regressions for sick plus personal leave were estimated with and without these fixed effects, the resulting estimates being very close to each other.

Table 2 presents a subset of the estimated coefficients for these regressions. Estimates in column 2.1 are taken from the regression for sick plus personal leave that includes year indicators as well as variables describing district, school, and individual characteristics. ${ }^{16}$ In contrast, the remaining equations in the table, because they employ district fixed effects, omit unchanging district measures as well as year indicators. With respect to demographic characteristics, equation

\footnotetext{
15 These high absence districts are small and are located in the co astal plain and the far western mountains.

16 The full set of estimated coefficients corresponding to equation 2.1 is given in Appendix Table A3, and descriptive statistics for the variables used are in Appendix Table A2.
} 
2.1 shows that female teachers, like female workers in the workforce at large, are absent more often than men. This difference is reflected not only in the dichotomous indicator for males, which reveals a difference of less than one day, but also in the statistical age-gender probability of giving birth in the year, derived from national data on birth rates. Together, these two variables imply a male-female difference of 3.9 sick plus personal days for two teachers aged 22 , but a difference of only one day for two 42 year-olds. ${ }^{17}$ The quadratic age coefficients imply that absences tended to rise at a diminishing rate (to age 57). Black and other nonwhite teachers took slightly less sick and personal leave than white teachers.

The experience indicators reveal a pattern that reflects the limited amount of sick and personal leave that new teachers can accumulate. In their second year, teachers took an average of 1.8 more days than they did in their first. This gap increased to 2.8 in their third and fourth years and then to more than three days after four years of experience. Inexperienced teachers therefore had considerably fewer absences due to illness and other personal reasons than those with at least several years' experience. As we note below, inexperienced teachers also took less vacation leave. Teachers who graduated from a college in a bordering state had slightly more absences than other teachers, which might reflect occasional trips home. Fewer days were taken by teachers with high test scores, with master's degrees, who had National Board certification, or who had graduated from a very competitive college. Teachers in schools with higher percentages

\footnotetext{
17 The maternity risk variable is the statistical probability (in 2000) that a woman would give birth in a year, based on her age alone. The source was actual births per 1,000 wo men in 2000: Statistical Abstract of the United States, 2004-05 (Table 85, p. 68). This probability rises from .0597 for women und er 20, to .0918 for women at least 20 but under 25, to .1079 for women 25-30, and falls thereafter to .0109 for women at least 40 but under 45 .Ichino and Moretti (2006, Table 1, p. 37) report that, overall, female workers in the U.S. average about three more days of illness-related absences than males, with a smaller difference for unmarried and childless workers. Although our maternity risk variable is based on the probability of giving birth, the study by Ich ino and M oretti suggests that it could also be picking up the effects of another biologically-based gender difference, namely the menstrual cycle.
} 
of free lunch recipients tended to have higher absence rates, and the same is true for the district free lunch percentage, but none of the estimated effects is very large on its own. For example, the coefficient for proportion eligible for free lunch in middle and high schools imply that increasing a school's free lunch share from the $25^{\text {th }}$ to the $75^{\text {th }}$ percentile would increase average absences for all the school's teachers of only about a quarter of a day per year. The effect for elementary schools is smaller. ${ }^{18}$ The district free lunch percentage has almost no effect on absences. As for proportion nonwhite, the school's proportion is positively associated with absences while the district's is negatively correlated. Although these estimates seem to give little reason for concern that low-income or minority students are experiencing very elevated rates of teacher absence, it will be important to examine the actual incidence of high absence rates, as we do in the next section.

The table's remaining three regressions employ district-by-year fixed effects - which mean that all coefficients reflect only differences within districts in a given year. Equation 2.2, which is directly comparable to equation 2.1 , produces very similar estimated coefficients. This similarity suggests that unaccounted-for differences across districts or over time are not important in explaining variation in sick plus personal days. Equation 2.3, which examines annual vacation leave, reveals several contrasts with the comparable equation for sick plus personal leave. Most striking is the disappearance of the maternity risk relationship, a sensible finding in light of the high likelihood that the reasons why young women might take sick or personal leave are quite unrelated to the timing of school vacations. A second difference is a reduction in the experience gradient. Teachers with 2-3 years experience take 1.5 vacation days

\footnotetext{
${ }^{18}$ For the $25^{\text {th }}$ and $75^{\text {th }}$ percentiles at each level, see Table 3 , note.
} 
more than novice teachers, compared to 2.8 more sick plus personal days. Because vacation leave accumulates at a rising rate, more is used in later years, until after 30 years, when it is presumably being saved to augment retirement benefits. In addition, in contrast to equation 2.2 , North Carolina college graduates take an extra half day of vacation, National Board certified teachers take an extra three quarters of a day, and the effects of free lunch and racial composition virtually disappear.

In order to arrive at a comprehensive measure of absences most likely associated with lost teaching time we summed all absences not associated with administrative reasons, shown in equation 2.4. By and large, the coefficients in this model reflect the patterns seen in equation 2.2, except for steeper age and experience gradients and the extra half day for in-state college graduates.

\section{Distributional Aspects of Teacher Absence}

Do teacher absences occur more frequently in schools serving low-income or minority students? If so, absences would join the list of unfavorable school characteristics that disproportionately affect disadvantaged students, such as having inexperienced teachers. ${ }^{19}$ Our data from North Carolina indicate that teacher absences do indeed have this kind of distributional impact. As shown in equations 2.2 and 2.4 in Table 2, otherwise similar teachers have slightly higher rates of absence when they teach in schools and districts where higher percentages of students are eligible to receive free lunches; equation 2.1 implies district-level differences as well, but with racial composition going in the opposite direction. But it is not

\footnotetext{
${ }^{19}$ For empirical studies of distributional patterns of school resources, see Betts, Rueben and Danenberg (2000) and Clotfelter, Ladd and Vigd or (2005).
} 
obvious that these regression results necessarily imply higher absence rates for low-income schools, because the regressions also indicate lower absence rates for inexperienced teachers, whom we know from previous work to be more numerous in these same kinds of schools and districts (Clotfelter, Ladd and Vigdor 2005 and Clotfelter, Ladd, Vigdor and Wheeler forthcoming). To understand the full distributional impact, therefore, one needs to compare actual rates of incidence by income level.

Table 3 presents tabulations showing for one year the average number of absences taken by teachers in schools falling into each quartile of schools defined by free lunch percentage. To allow for the differences in take-up of free lunch by school level, the averages are shown separately for each school level. For each level, the average number of teacher sick days is highest in the bottom income quartile and lowest in the most affluent quartile. The differences between top and bottom quartiles in mean sick days is on the order of one day per teacher or less. Likewise, personal leave tends to be highest in low-income schools, but the differences across the income spectrum are not large. In contrast, annual vacation leave tends to rise with income quartile (recall, however, that reporting conventions differ across districts). Because more affluent schools tend to have more experienced teachers, and those teachers have more access to annual leave days, this result is not surprising. In any case, one would expect that days of annual leave do not carry with them the same potential for lost instruction time that sick days do, since these absences require a principal's approval and are thus most often taken during teacher work days rather than on school days.

If teacher absences are harmful to learning, they are apt to be especially damaging if they are school-wide and occur year after year. Indeed, persistently high absenteeism appears to be 
one hallmark of troubled schools. ${ }^{20}$ For this reason, we sought to find out if some schools in our sample tend to experience consistently high rates of absence and, if so, whether those schools serve low-income students. We looked at schools that had been, in at least five of the ten years covered by our data, in the highest quartile of average sick plus personal days. Out of 2,094 schools that were in our data for at least five years, 559 qualified by this criterion. Table 4 shows the prevalence of high-absence schools by schools' income quartile over this period. Each cell in the table gives the percentage of schools, by income level, that fell into the highest absence quartile. ${ }^{21}$ The table shows, first of all, that elementary schools are more likely to fall into the high-absence category than middle schools, and that high schools are least prone among all levels. This difference reflects in part the higher average rates of sick leave in elementary schools, as shown also in Table 3, but it could also be a reflection of the smaller size of elementary schools, and thus their tendency for wider swings in average absence rates from year to year. Within each level, however, the pattern is quite clear, with high-absence schools being much more prevalent among those with low-income students than those serving student populations with higher average family incomes. For example, whereas a quarter of middle schools fell into the persistently-high absence category, fewer than one in 12 middle schools serving the most affluent quarter of students had such consistently high rates of absence. In sum, low-income students in North Carolina face an appreciably higher chance than affluent ones of attending a school with persistently high rates of teacher absence.

\footnotetext{
${ }^{20}$ See, for example, Dell'Angela and Little (2006) and Imants and Zoelen (1995).

${ }^{21}$ Percentages are weighted by full-time equivalent teachers. See Table 4 for a detailed description of the calculations.
} 


\section{Absences and Student Achievement}

Common sense suggests that teacher absences will impede students' academic progress. To see if the data are consistent with this reasoning, we estimated variations of a standard valueadded model of the form:

$$
\mathrm{A}_{\mathrm{it}}=a \mathrm{~A}_{\mathrm{it}-1}+b \mathrm{Abs}_{\mathrm{it}}+c \mathrm{X}_{\mathrm{it}}+\mathrm{u}_{\mathrm{it}}
$$

where $\mathrm{A}_{\mathrm{it}}$ is student $\mathrm{i}$ 's achievement test score in year $\mathrm{t}$ (normalized with mean zero and unit standard deviation), $\mathrm{Abs}_{\mathrm{it}}$ is the number of sick plus personal days taken by student i's teacher in year $\mathrm{t}, \mathrm{X}_{\mathrm{it}}$ is a vector of student, school, and teacher characteristics, $\mathrm{u}_{\mathrm{it}}$ is an error term, and $a, b$ and $c$ are estimated coefficients or vectors of coefficients. In this model, the coefficient on number of sick plus personal days taken by a student's teacher, $b$, measures the average difference in achievement associated with those absences, net of any teaching done by substitute teachers.

We used ordinary least squares to obtain the initial estimates reported in Model A of Table 5. The richness of the available administrative data made it possible for us to match most North Carolina students in grades 4 and 5 to the classroom teachers who taught them math and English. This matching enabled us to compare the academic achievement of students whose teachers differed in the number of sick days taken, holding constant a long list of other student, teacher, and school characteristics, as well as the student's previous achievement score. As shown in the table, for math achievement, the coefficient for the absence variable is -0.0023 (s.e. $=0.0001)$. This finding implies that having a teacher with ten additional sick days in a year would be associated with a reduced math test score of about $2.3 \%$ of a standard deviation. ${ }^{22}$ By

\footnotetext{
22 The complete set of estimates is given in Appendix Table A2.
} 
comparison, this effect is slightly larger than that of changing schools and about half the size of the effect of being eligible for the subsidized lunch program. For reading, the coefficient is less than half as large, implying that the same 10-day increase in sick days would be associated with a lower test score of about $1 \%$ of a standard deviation.

The coefficients that emerge from this simple ordinary least squares model, however, are likely to be biased. One possibility is that teacher absences may be correlated with unmeasured aspects of teacher ability or effort, which would cause omitted variables bias in the coefficient of absences. In this case, the absence variable would reflect the combined effects of otherwise unmeasured characteristics of teachers correlated with high absence rates and the effect of the absences themselves. A second possibility that would threaten the validity of OLS is if absences are influenced by students' performance, thus subjecting OLS to simultaneity bias.

To account for the possibility of bias due to omitted variables correlated with absences, we followed the approach of Miller, Murnane and Willett (2006) by estimating an alternate specification using teacher fixed effects. Such an approach depends entirely on variation over time in a teacher's absences to estimate the relationship between absences and student achievement. Additive time-invariant teacher characteristics, which could include unmeasured ability or effort, are swept away and thus cannot lead to omitted variables bias. These equations with teacher fixed effects yielded somewhat smaller, though statistically significant, coefficients. These fixed effects models imply that 10 additional days of teacher absence would be associated with a decline of $1.7 \%$ of a standard deviation in math achievement and $0.9 \%$ s.d. in reading. ${ }^{23}$ These magnitudes are less than that obtained by Miller, Murnane and Willett (2007) for math, of

\footnotetext{
${ }^{23}$ Ten days is approximately one standard deviation in the absence measure.
} 
$3.3 \%$, but of the same order of magnitude. By way of comparison, our basic fixed effect achievement regression implies that having a teacher with 1-2 years experience is associated with higher achievement of $7.7 \%$ s.d. in math and $4.6 \%$ in reading. ${ }^{24}$

The endogeneity problem is more difficult to address. In the absence of a good instrumental variable to deal with this problem, we adopted one additional strategy in an effort to pin down the causal effect of teacher absences on student achievement. If teacher absences depress student learning, we reasoned, some absences might cause more damage than others. In particular, teacher absences that occur early in the year would probably be less harmful than those occurring in the second half, in the run-up to the annual testing period near the end of school. Another possibility we considered is that absences that were covered by a certified substitute might be less harmful than those covered by an uncertified substitute.

We therefore estimated two variants of the achievement model described above. The first variant divided teacher absences according to the month they occurred - July to December and January to June. As shown in Table 5, Model B, the estimated coefficients of teacher absence differ significantly between the first and second semesters, with the second semester effects being about three times as large as the first semester effect in math. Although the imposition of teacher fixed effects reduces most of the estimated coefficients, those for the two semesters remain statistically different from each other. These results are strongly suggestive of a causal link between teacher absence and student achievement in elementary grades.

\footnotetext{
24 All of the estimates presented in the text and tables are based on specifications in which number of days of sick plus personal days of absence enter linearly. We explored other functional forms, including quadratic, square root, and discrete indicators for ranges of absences, but the implied effects were very close to those due to the linear specification.
} 
By contrast, we found much smaller differences between the effects of absences when absences are divided by the type of substitute, as shown in Model C. Although, as expected, absences covered by an uncertified substitute were associated with larger declines in achievement than those covered by certified substitutes, the differences are statistically significant in only one of the two fixed effects equations. ${ }^{25}$

If absences do indeed depress student achievement, it is natural to worry about whether this effect might be more severe among certain, more vulnerable students. Indeed, Miller, Murnane and Willet (2007) suggest that such a difference in impact might explain the contrast in magnitudes between their estimates and ours. We therefore estimated a series of equations of the basic form of Model A, adding, seriatim, interaction terms that would indicate a differential influence. These variants are shown in Table 6. The fixed effects models show that the deleterious effect of teacher absences is greater among students: who are in rural districts; who are non-black nonwhites, compared to whites (for math only); who are eligible for the free lunch program (math only, at the 10\% level only); and who scored below average in the previous year. Students whose parents did not graduate from high school or who were taught by a teacher with two or fewer years of experience showed no statistically significant difference in effect of absences, except for the anomalous result that those taught by inexperienced teachers actually gained a small amount in math from additional teacher absences. Among these differential effects, the largest was for low-achieving students. In the fixed effect equation for math, 10 days

\footnotetext{
${ }^{25}$ As an additional check on the validity of our estimates, we sought to verify that our results were not being driven by a compara tively small number of high-abs ence teachers. Thus we re-estimated the basic Model A regressions, o mitting teachers with more tha 50 abse nces in a year. The resulting estimated coefficie nts actually showed a somewhat larger effect for absences in math ( -.0018 vs. -0.0017 for the full sample, with fixed effects) but no difference in reading.
} 
of teacher absence would be associated with a drop of $3.3 \%$ of a standard deviation in score, compared to only $0.3 \%$ s.d. for above-average achievers. ${ }^{26}$

We believe that the teacher fixed effect model goes a long way in dealing with concerns that teacher absences are endogenous. To be sure, our method is valid so long as there are no time-varying determinants of teacher absence that correlate with unobserved determinants of student achievement, which would be true in what we see as the likely case that year-to-year variation in a teacher's absences are driven by exogenous health effects rather than the teacher's response to that year's class of students. Taken at face value, the estimated coefficients from our fixed-effect model (Model A in Table 5) imply that the achievement level for a student in grades 4-5 will fall .0017 of a standard deviation in math and .0009 in reading for each day his or her teacher is absent in the year. To put these effects in context, they imply, for example, that 10 additional days of absence would be associated with declines in achievement equal to about onefifth the advantage of having a teacher with 1-2 years experience, compared to having a novice teacher. $^{27}$

\section{Can Absences be Reduced through Incentives?}

Teacher absences are socially costly. Suppose we accept as valid the estimates from the teacher fixed effect models above. There are two ways to translate these test scores into social costs. One would be to rely on estimates of the relationship between test scores and lifetime earnings, or some other long range outcome. A simpler method would be to consider estimates

\footnotetext{
26 It is worth noting that we found no statistically significant difference in coefficie nts by student ge nder.

${ }^{27}$ For math, 10 days of absence implies a reduction of .017 s.d., which is $23 \%$ of the .0736 s.d. difference associated with having a teacher with 1-2 years experience. For reading, the comparable calculation is $.009 / .0467$, or $19 \%$.
} 
of the cost of offsetting these test score declines, based on existing interventions. ${ }^{28}$ Two recent analyses, of the Tennessee STAR experiment and of a teacher retention bonus program in North Carolina, suggest that the cost of increasing one student's test score in one subject by $1 \%$ of a standard deviation is in the range of $\$ 36$ to $\$ 39$ in current dollars. ${ }^{29}$ Assuming a class size of 25 students, and that each teacher teaches both math and reading, the achievement costs of a single absence are on the order of $\$ 250 .{ }^{30}$ Beyond these very rough calculations of the instructional costs of a teacher absence, school districts also face the cost of paying a daily wage rate to a substitute teacher, which could amount to as much as $\$ 90 .^{31}$ The existence of both of these types of costs suggests that a policy of unlimited free absences for teachers would be socially inefficient.

From a policy perspective, it would be useful to know how teachers respond to policies that impose some cost on the decision to take an absence. The structure of teacher absence policy in North Carolina provides us with an opportunity to address this question. As reviewed above, teachers can take up to 10 sick days per year without penalty, with unused sick days being

\footnotetext{
${ }^{28}$ This approach is reasonable under the presumption that interventions can be scaled upwards or downwards at constant average cost to deliver a precise dose of test score improvement. Given the potential for non-linear dose response in most interventions, this assumption is clearly questionable. Our goal here is to provide a ballpark estimate of the instructional costs associated with the typical teacher absence, not to propose that any particular intervention be applied to students of an absent teacher.

${ }^{29}$ See Krueger (1999) and Clotfelter, Glennie, Ladd and Vigdor (forthcoming), with details of these calculations in the latter. Using less conservative assumptions, the former study suggests an even larger cost estimate, on the order of $\$ 100$.

30 (math coefficient + reading coefficient) $* 25$ students $/$ class $* \$ 36$.

${ }^{31}$ In the 2006/07 school year, the Wake County Public School System, the state's second largest at the time, paid a daily wage of $\$ 84$ to certified substitute teachers. Adding the $7.65 \%$ employer's share of payroll taxes for social security and Medicare brings the cost to $\$ 90$.
} 
carried over into subsequent school years. Whenever the supply of "free" sick days is exhausted, teachers may take up to 20 additional sick days, at a cost of $\$ 50$ per day. Appendix Table A2 indicates that about 15,000 of the se extended sick days were taken in the 2000/01 school year. In that same year, teachers took over 535,000 "free" sick days.

In any school year, a teacher's supply of free sick days will depend on her experience level and on the number of sick days taken in prior years. Thus the impact of the $\$ 50$ charge for extended sick days can be identified by comparing teachers who have taken a comparable number of sick days in a given year, exploiting the fact that some teachers will exhaust their supply of free days earlier than others.

To analyze the impact of the $\$ 50$ charge on teacher absences, we estimated a Cox proportional hazard model, analyzing a teacher's decision to take sick day $t$ conditional on having already taken $t$ - 1 sick days in a given school year. Our estimated model takes the form:

$$
\operatorname{logit}\left[\lambda\left(t_{\mathrm{ijs}}\right)\right]=\alpha+\beta_{1} X_{\mathrm{ij}}+\beta_{2} X_{\mathrm{js}}+\beta_{3} C_{\mathrm{tij}}
$$

where $i$ indexes teachers, $j$ indexes school years, and $s$ indexes schools. The term $\lambda\left(t_{\mathrm{ijs}}\right)$ represents the conditional probability that $t$ is the last sick day taken by a teacher in a given year, conditional on the fact that sick days 1 through $t$ - 1 were not the last. The specification controls for a vector of teacher characteristics, $X_{\mathrm{ij}}$, and school characteristics $X_{\mathrm{js}}$. The independent variable of interest is the cost of sick day $t$ for teacher $i$ in year $j, C_{\mathrm{tij}}{ }^{32}$ The impact of the cost

\footnotetext{
${ }^{32}$ Ideally, we would prefer to estimate a model that used the cost of sick day $\mathrm{t}+1$ as the independent variable of interest. Unfortunately, we lack reliable data on the size of each teacher's bank of available free sick days. When we attempted to impute this information, using the subsample teachers with complete histories of employment and sick days taken, we were unable to accurately forecast which teachers would be required to take extended sick days in a given year. There are a number of conceivable reasons for these forecast errors. Teachers actually accrue sick days at the rate of one per month, rather than ten per year, however our database is not
} 
parameter on the dependent variable is identified by comparing teacher/year observations with identical values of $t$, but different values of $C_{\mathrm{tij}}$. For example, an inexperienced teacher might start paying the penalty on the $12^{\text {th }}$ sick day, while more experienced teachers with a greater supply of banked sick leave would not face the penalty until many more days had been taken.

Table 7 presents the results of estimating equation (2) with data on 341,420 teacher/year observations between 1995 and 2005 . The number of absences taken by these teachers over the time period was more than 2.6 million. The table entries are hazard ratios, which carry a different interpretation than typical regression coefficients. An independent variable associated with a hazard ratio greater than one is a factor that makes it more likely that a teacher will stop taking absences after absence $t$, while variables associated with hazard ratios less than one make it less likely that a teacher will stop taking absences.

The variable of interest, the cost in dollars of taking absence $t$, has a hazard ratio of 1.003, which is significantly greater than one. To determine the impact of a $\$ 50$ cost, this ratio needs to be raised to the 50th power. These results thus indicate that associating a $\$ 50$ penalty with sick day $t$ increases the likelihood that no further sick days will be taken by the affected teacher in the given year by $16 \%$, compared to a situation in which there were no cost to the teacher of taking an additional sick day.

To evaluate the magnitude of this impact, suppose that the same effect would result from applying the $\$ 50$ penalty to all sick days including the first. Suppose further that teachers take an

sufficiently detailed to allow us to observe the mon th in which a sick day was taken in all cases. Teachers also occasion ally have op tions to "bor row" sick days from other teachers, a practice that may not be fully documented in our data. Our use of the cost of sick day $t$ in place of the cost of sick day $t+1$ implies that we have some degree of errors-in-variables bias, which should lead us to understate the impact of monetary incentives on absence taking. When we attempted to use our estimates of the cost of sick day $t+1$ instead, we obtained coefficients even more attenuated than the ones presented here. 
aver age of seven sick days per year, and that probability of taking sick day $t$, conditional on taking $t-1$, is a constant value. Simple arithmetic shows that this constant value is approximately equal to $0.875 .^{33}$ The likelihood of sick day $t$ being the last, conditional on taking sick day $t$, is thus 0.125 . Increasing this value by $16 \%$, to 0.145 , would reduce the mean number of absences taken to 5.9.

The average teacher would be charged about $\$ 300$ for absences in each school year. This sum could be offset by increasing base salaries. Districts could increase salaries still further by applying cost savings associated with the 1.1 averted absences per year. A revenue-neutral policy change, incorporating $\$ 100$ in savings associated with averted payments to substitute teachers, would thus increase teacher salaries by roughly $\$ 400$ per year, in exchange for teachers accepting a $\$ 50$ charge for each sick day taken. ${ }^{34}$ Districts willing to compensate teachers for averted educational costs could push the base salary increase still higher. ${ }^{35}$

The remaining teacher and school-level covariates in the hazard model each display relationships with the decision to stop taking absences that are fully consistent with the coefficients in Table 2, a correspondence that increases our confidence that the hazard model has

${ }^{33}$ Under the stated assumptions, referring to the conditional probability as $\mathrm{p}$, the expected number of sick days taken is $p+p^{2}+\ldots+p^{T}$, where $T$ is the length of the school year. If we replace this ex pression with an infinite series $\sum p^{i}$, the expected value can be expressed as $p /(1-p)$. The term $p /(1-p)$ is equal to 7 when $p=7 / 8$. The impact of extending the expecte $d$ value to an infinite series is negligible; if $p=7 / 8$ then only one in 27.5 billion tea chers will be expected to take as many as 180 sick days.

34 Politically, this policy would be easier to implement if advertised as a $\$ 400$ bonus for perfect attendance, reduced by $\$ 50$ each day, with penalties accruing to teachers who took more than 8 sick days in a given year. Note, however, that risk-averse tea chers might reject a policy that introduced the possibility of sa lary reductions even if their expected comp ensation incre ased.

35 Recall also that our estimate of the impact of the $\$ 50$ penalty likely suffers from attenuation bias. Thus the net savings in terms of absences averted would likely be higher than this estimate. 
identified a true deterrent effect ass ociated with the $\$ 50$ penalty.

\section{Conclusion}

Teacher absences are important for four main reasons. First, hiring substitute teachers not only costs money, but it also consumes valuable administrative resources, often in the mundane form of early morning phone calls by principals or assistant principals. In North Carolina, sick and personal leave represent slightly more than $4 \%$ of the standard 180 -day school year, a rate typical in American public schools, though quite small in comparison with rates observed in other contexts. Although absence rates in teaching tend to be higher than ostensibly comparable figures for other similar occupations and sectors, however, they are not wildly out of line. In fact, one could argue that it is precisely the opportunity to take the occasional day off that makes teaching attractive to many people with children. Except for schools and districts with persistently high rates of absence, then, the rate of teacher absences itself should probably not be a cause for great concern.

The second reason to pay attention to teacher absences is their effect on student achievement: when regular teachers are not in the classroom, opportunities for students to learn are cut short. This common sense conclusion is bolstered by statistical evidence showing that students whose teachers miss more days for sickness score lower on state achievement tests. The third reason to worry about teacher absences is that they occur with greater frequency in lowincome schools. Teacher absences therefore join other characteristics of teachers that are distributed unequally across schools and should therefore be included in discussions of equity in the provision of public schooling. The fourth reason to pay attention to teacher absences is that, because the demand for absences is price-elastic, they can be influenced by school district 
compensation policies. Our results suggest that teachers' valuation of a marginal sick day is in some cases less than $\$ 50$, which is in turn less than even the most conservative estimates of the marginal social cost of an absence.

Overall, then, policies that create or increase incentives to reduce the number of absences teachers take can be advocated on two fronts. From an efficiency standpoint, these policies have the potential to simultaneously raise teachers' expected compensation and reduce districts' expected costs. ${ }^{36}$ From an equity perspective, policies that reduce absences have the potential to reduce one of the many resource disparities between high- and low-poverty schools.

Previous research suggests that policies regarding the number of absences, the ability to carry forward unused sick days, the benefits if any of not using all allowable days, and schoollevel requirements about reporting absences all have the potential to influence the actual rate of teacher absenteeism. In assessing the desirability of adjusting such policies, policy makers must weigh the costs of absences - budgetary, administrative, and educational - against the degree to which more lenient policies might make teaching an attractive career option.

\footnotetext{
${ }^{36}$ Depen ding on the degree of risk a version am ong teachers, the result may ind eed represent a Par eto improvement.
} 


\section{References}

Banerjee, Abhijit, and Esther Duflo. “Addressing Absence.” Journal of Economic Perspectives 20 (Winter 2006) 117-132.

Betts, Julian R., Kim S. Rueben, and Anne Danenberg, Equal Resources, Equal Outcomes? The Distribution of School Resources and Student Achievement in California 9San Francisco: Public Policy Institute of California, 2000).

Www.ppic.org/main/publication.asp? $\mathrm{i}=64,6 / 28 / 05$.

Bradley, Steve, Colin Green, and Gareth Leeves, "Worker Absence and Shirking: Evidence from Matched Teacher-School Data," unpublished paper, Lancaster University, December 19, 2005.

Chaudhury, Nazmul, Jeffrey Hammer, Michael Kremer, Karthik Muralidharan, and F. Halsey Rogers, "Missing in Action: Teacher and Health Worker Absence in Developing Countries," Journal of Economic Perspectives 20 (Winter 2006), 91-116.

Clotfelter, Charles T., Elizabeth Glennie, Helen F. Ladd, and Jacob L.Vigdor, "Would Higher Salaries Keep Teachers in High-Poverty Schools? Evidence from a Policy Intervention in North Carolina," Journal of Public Economics, forthcoming.

Clotfelter, Charles T., Helen F. Ladd, and Jacob L.Vigdor, "Who Teaches Whom? Race and the Distribution of Novice Teachers," Economics of Education Review 24 (2005), 377-392.

Clotfelter, Charles T., Helen F. Ladd, Jacob L.Vigdor, and Justin Wheeler, "High Poverty Schools and the Distribution of Teachers and Principals," North Carolina Law Review, forthcoming.

Dell'Angela, Tracy and Darnell Little, "Teachers Miss Days; Poor Kids Miss Out: Educators at Some Struggling Schools Take Most Time Off, Analysis Shows," Chicago Tribune, September 25, 2006.

Duflo, Esther, and Rema Hanna, "Monitoring Works: Getting Teachers to Come to School,” National Bureau of Economic Research Working Paper 11880, 2005.

Ehrenberg, Ronald G., Randy A. Ehrenberg, Daniel I. Rees and Eric L. Ehrenberg, "School District Leave Policies, Teacher Absenteeism, and Student Achievement," Journal of Human Resources 26 (1, 1991), 72-105.

Glewwe, Paul, Nauman Ilias, and Michael Kremer, “Teacher Incentives,” National Bureau of Economic Research Working Paper 9671, April 2003. 
Ichino, Andrea and Enrico Moretti, "Biological Gender Differences, Absenteeism and the Earning Gap," National Bureau of Economic Research Working Paper 12369, July 2006.

Imants, Jeroen and Ad Van Zoelen, “Teachers' Sickness Absence in Primary Schools, School Climate and Teachers' Sense of Efficacy," School Organization 15 (1995), 77-86.

Krueger, Alan B., "Experimental Estimates of Education Production Functions," Quarterly Journal of Economics 114 (May 1999), 497-532.

Lindeboom, Maarten and Marcel Kerkofs, "Multistate Models for Clustered Duration Data - An Application to Workplace Effects on Individual Sickness Absenteeism," Review of Economics and Statistics 82 (November 2000), 668-684.

Miller, Raegen T., Richard J. Murnane, and John B. Willett, “The Impact of Teacher Absences on Student Achievement," unpublished paper, Harvard Graduate School of Education, July 2006.

Miller, Raegen T., Richard J. Murnane, and John B. Willett, "Do Worker Absences Affect Productivity? The Case of Teachers," unpublished paper, Harvard Graduate School of Education, March 2007.

Podgursky, Michael, “Check the Facts: Fringe Benefits,” Education Next, No. 3, 2003. http://www.hoover.org/publications/ednext/3347981.html, 3/2/07.

Roza, Marguerite, Frozen Assets: Rethinking Teacher Contracts Could Free Billions for School Reform, Education Sector Report, January 2007.

http://www.educationsector.org/usr doc/FrozenAssets.pdf, 3/2/07

U.S. Bureau of Labor Statistics, Labor Force Statistics from the Current Population Survey, 2006.

Www.bls.gov/cps/cpsaat47.pdf, 10/5/06

$\mathrm{R}: \backslash$ teachq $\backslash$ ctcdocs $\backslash$ absenteelabsences 100507 
Figure 1. Distribution of Absences by Years of Experience, 2000/01

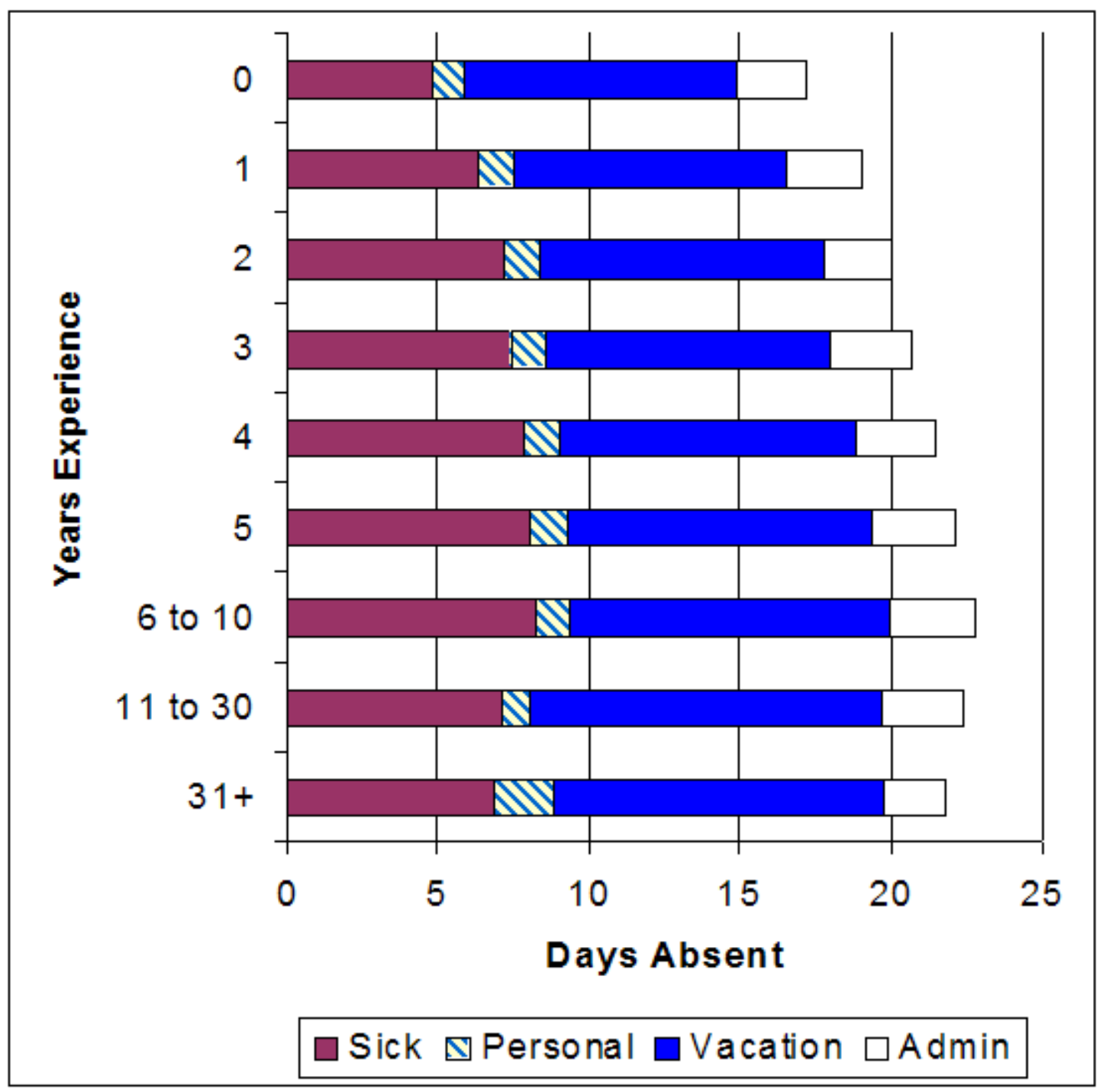

$3 / 14 / 07$ 
Figure 2. Frequency Distribution, Sick and Personal Leave

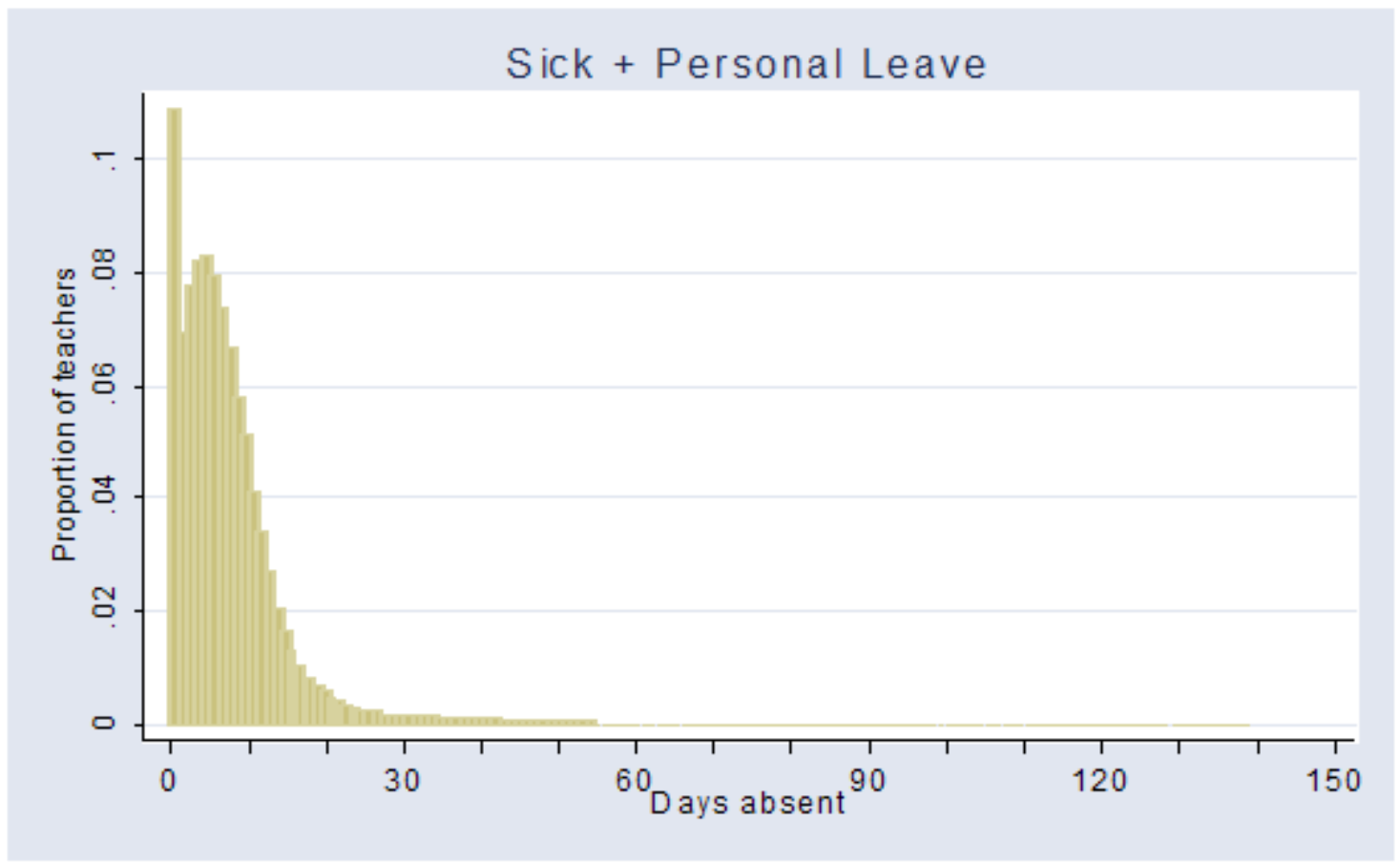

Figure 3. Frequency Distribution, Annual (Vacation) Leave

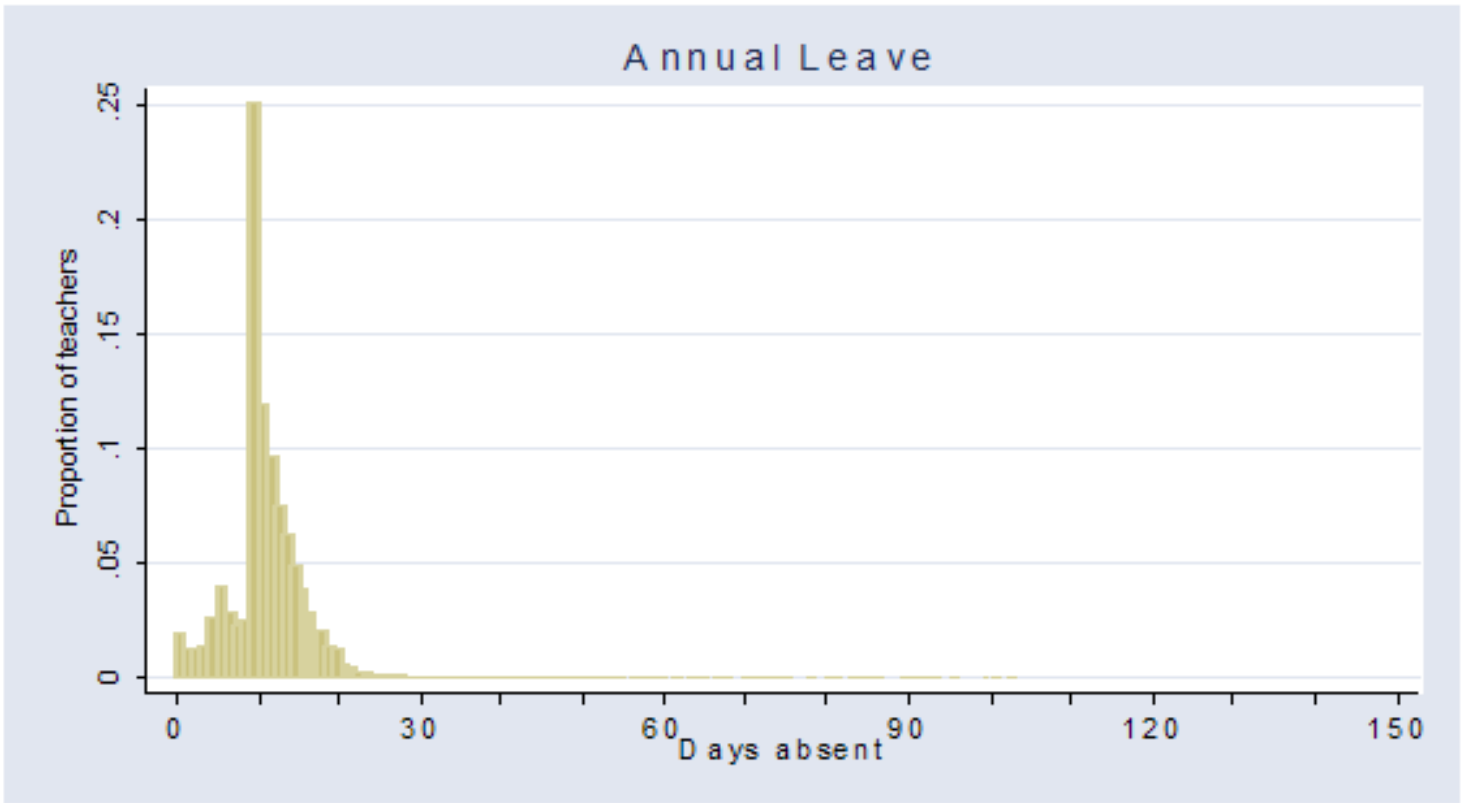

Note: Full-time teachers working at least 10 month per year for combined years 1995-2004. $3 / 21 / 07$ 
Figure 4. Average Teacher Absences, by District, 2003/04

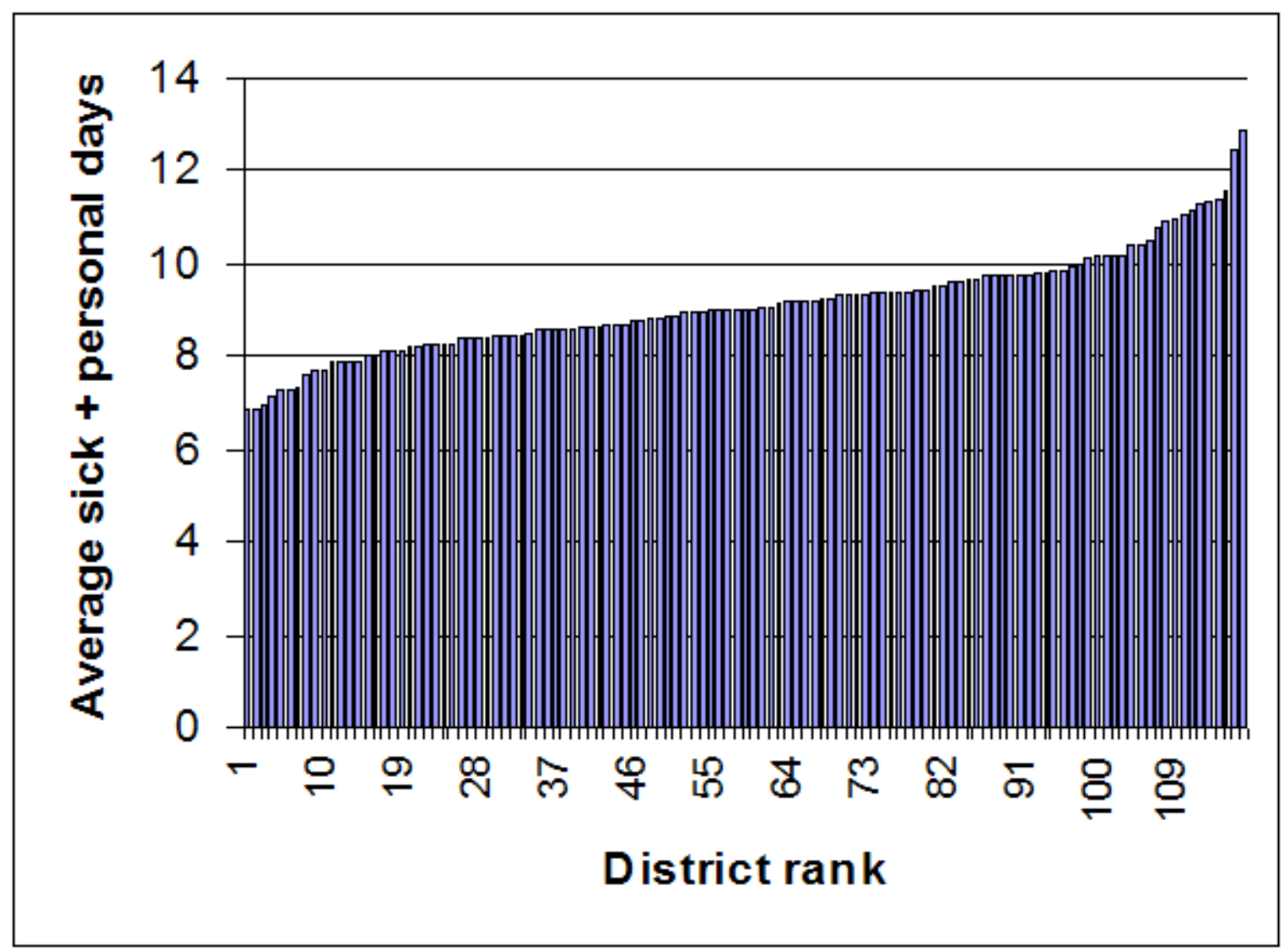

$3 / 21 / 07$ 
Figure 5. Plot of District Average Rate of Sick plus Personal Leave Absences in 2000/01 and $2003 / 04$

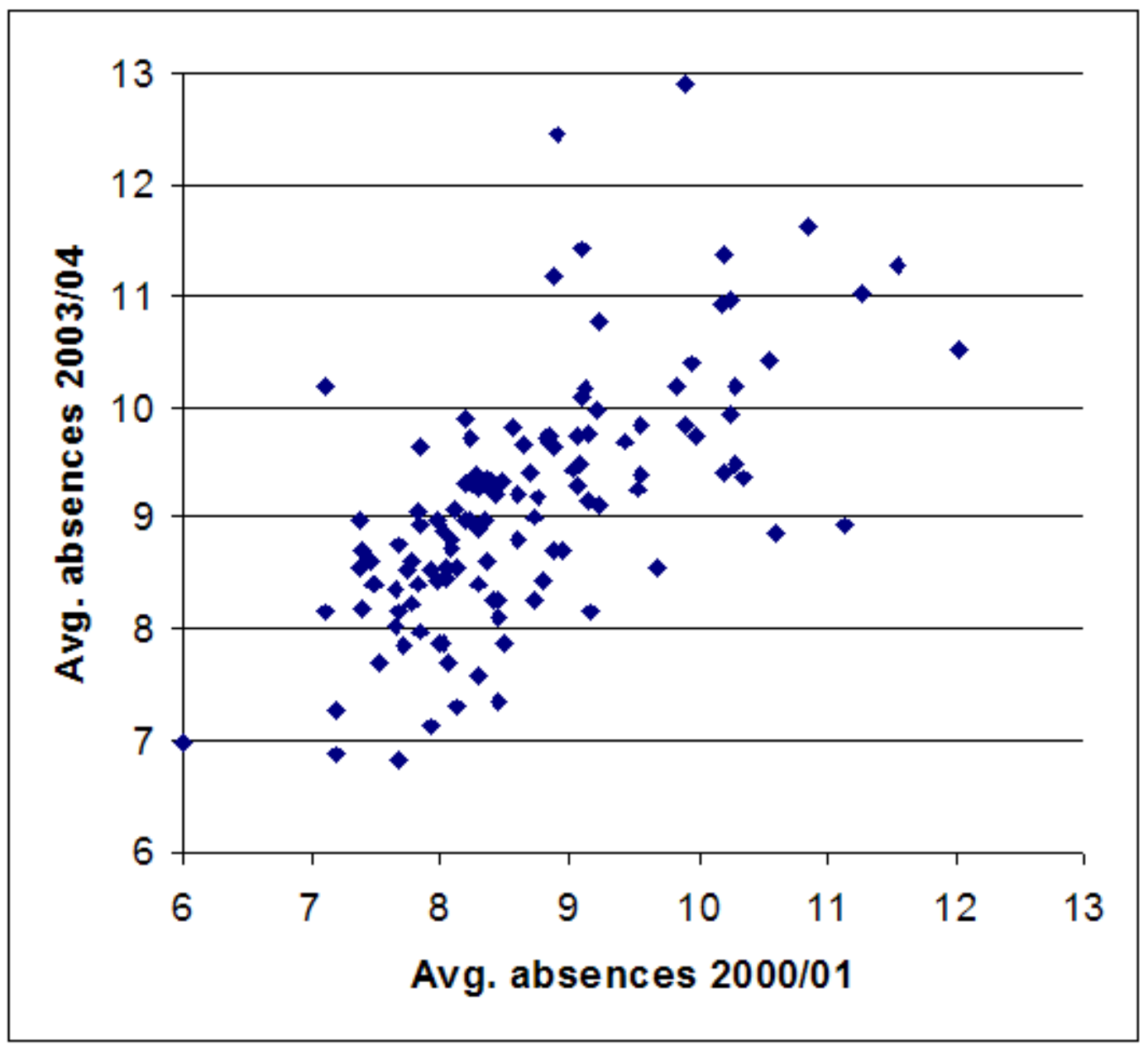

Note: The correlation coefficient between the 2000/01 and 2003/04 absences is .653.

$3 / 29 / 07$ 
Table 1. Mean Absences, by Type 1994/95-2003/04

\begin{tabular}{llllll}
\hline \multicolumn{5}{c}{} & \multicolumn{5}{c}{ Type of absence } \\
\hline Year & Total & Sick leave & $\begin{array}{l}\text { Personal } \\
\text { leave }\end{array}$ & $\begin{array}{l}\text { Annual } \\
\text { vacation leave }\end{array}$ & Administrative \\
\hline $1994 / 95$ & 24.0 & 7.2 & 0.6 & 13.3 & 2.3 \\
$1995 / 96$ & 23.1 & 7.0 & 0.6 & 12.9 & 2.1 \\
$1996 / 97$ & 22.8 & 7.0 & 0.6 & 12.3 & 2.3 \\
$1997 / 98$ & 21.9 & 6.9 & 0.5 & 11.5 & 2.4 \\
$1998 / 99$ & 22.0 & 7.1 & 0.6 & 11.3 & 2.4 \\
$1999 / 2000$ & 21.5 & 6.9 & 1.1 & 10.9 & 2.4 \\
$2000 / 01$ & 21.7 & 7.2 & 1.1 & 10.8 & 2.5 \\
$2001 / 02$ & 20.4 & 6.9 & 1.1 & 10.0 & 2.3 \\
$2002 / 03$ & 20.6 & 7.1 & 1.2 & 9.9 & 2.3 \\
$2003 / 04$ & 22.0 & 7.6 & 1.2 & 10.4 & 2.7 \\
\hline
\end{tabular}

Notes: Table includes teachers working at least 10 months. Sick leave includes sick leave, extended sick leave, and sick leave bank; personal leave includes personal leave, absence with deduction, absence without pay, voluntary shared leave, child involvement leave, and other absence; annual vacation leave includes annual leave and annual leave for catastrophic illness; and administrative includes absences without deduction. See Appendix Table A1 for a complete list of leave categories.

Source: North Carolina Education Research Data Center. (sample 1, 1A)

$3 / 21 / 07$ 
Table 2. Selected Coefficients from Regressions Explaining Teacher Absences, Pooled Data for $1994 / 95$ to $2003 / 04$

\begin{tabular}{|c|c|c|c|c|}
\hline & 2.1 & 2.2 & 2.3 & 2.4 \\
\hline $\begin{array}{l}\text { Depen dent variable } \\
\text { District-by year }\end{array}$ & $\begin{array}{l}\text { Sick and } \\
\text { personal } \\
\text { leave }\end{array}$ & $\begin{array}{l}\text { Sick and } \\
\text { personal } \\
\text { leave }\end{array}$ & $\begin{array}{c}\text { Annual (vacation) } \\
\text { leave }\end{array}$ & $\begin{array}{l}\text { Sick, personal and } \\
\text { vacation leave }\end{array}$ \\
\hline fixed effects? & No & Yes & Yes & Yes \\
\hline Male & $\begin{array}{l}-.716 \\
(.066)\end{array}$ & $\begin{array}{l}-.735 \\
(.067)\end{array}$ & $\begin{array}{l}-.251 \\
(.025)\end{array}$ & $\begin{array}{l}-.986 \\
(.075)\end{array}$ \\
\hline Matern ity probability & $\begin{array}{l}34.348 \\
(.811)\end{array}$ & $\begin{array}{l}34.274 \\
(.812)\end{array}$ & $\begin{array}{l}1.140 \\
(.309)\end{array}$ & $\begin{array}{l}35.411 \\
(.910)\end{array}$ \\
\hline Black & $\begin{array}{l}-.387 \\
(.118)\end{array}$ & $\begin{array}{l}-.322 \\
(.120)\end{array}$ & $\begin{array}{l}.241 \\
(.046)\end{array}$ & $\begin{array}{l}-.083 \\
(.135)\end{array}$ \\
\hline Other no nwhite & $\begin{array}{l}-.342 \\
(.279)\end{array}$ & $\begin{array}{l}.011 \\
(.282)\end{array}$ & $\begin{array}{l}-.130 \\
(.107)\end{array}$ & $\begin{array}{l}-.118 \\
(.316)\end{array}$ \\
\hline Age & $\begin{array}{l}.127 \\
(.019)\end{array}$ & $\begin{array}{l}.126 \\
(.018)\end{array}$ & $\begin{array}{l}.169 \\
(.007)\end{array}$ & $\begin{array}{l}.295 \\
(.021)\end{array}$ \\
\hline Age squared (x.01) & $\begin{array}{l}-.112 \\
(.022)\end{array}$ & $\begin{array}{l}-.112 \\
(.022)\end{array}$ & $\begin{array}{l}-.209 \\
(.008)\end{array}$ & $\begin{array}{l}-.321 \\
(.024)\end{array}$ \\
\hline \multicolumn{5}{|l|}{ Experience } \\
\hline 1 Year & $\begin{array}{l}1.843 \\
(.083)\end{array}$ & $\begin{array}{l}1.838 \\
(.083)\end{array}$ & $\begin{array}{l}1.152 \\
(.032)\end{array}$ & $\begin{array}{l}2.991 \\
(.093)\end{array}$ \\
\hline 2-3 Years & $\begin{array}{l}2.794 \\
(.077)\end{array}$ & $\begin{array}{l}2.774 \\
(.077)\end{array}$ & $\begin{array}{l}1.466 \\
(.029)\end{array}$ & $\begin{array}{l}4.222 \\
(.086)\end{array}$ \\
\hline 4-5 Years & $\begin{array}{l}3.536 \\
(.091)\end{array}$ & $\begin{array}{l}3.575 \\
(.113)\end{array}$ & $\begin{array}{l}1.668 \\
(.035)\end{array}$ & $\begin{array}{l}5.243 \\
(.104)\end{array}$ \\
\hline 6-10 Years & $\begin{array}{l}3.472 \\
(.105)\end{array}$ & $\begin{array}{l}3.566 \\
(.113)\end{array}$ & $\begin{array}{l}2.143 \\
(.043)\end{array}$ & $\begin{array}{l}5.709 \\
(.126)\end{array}$ \\
\hline 11-30 Years & $\begin{array}{l}2.108 \\
(.140)\end{array}$ & $\begin{array}{l}2.280 \\
(.158)\end{array}$ & $\begin{array}{l}2.425 \\
(.060)\end{array}$ & $\begin{array}{l}4.704 \\
(.177)\end{array}$ \\
\hline Over 30 Years & $\begin{array}{l}4.834 \\
(.187)\end{array}$ & $\begin{array}{l}4.983 \\
(.198)\end{array}$ & $\begin{array}{l}1.560 \\
(.076)\end{array}$ & $\begin{array}{l}6.543 \\
(.222)\end{array}$ \\
\hline $\begin{array}{l}\text { Graduated North Carolina } \\
\text { college }\end{array}$ & $\begin{array}{l}-.013 \\
(.041)\end{array}$ & $\begin{array}{l}-.010 \\
(.041)\end{array}$ & $\begin{array}{l}.584 \\
(.016)\end{array}$ & $\begin{array}{l}.573 \\
(.046)\end{array}$ \\
\hline $\begin{array}{l}\text { Graduated college in state } \\
\text { bordering NC }\end{array}$ & $\begin{array}{l}.297 \\
(.074)\end{array}$ & $\begin{array}{l}.321 \\
(.074)\end{array}$ & $\begin{array}{l}.156 \\
(.028)\end{array}$ & $\begin{array}{l}.476 \\
(.084)\end{array}$ \\
\hline
\end{tabular}




\begin{tabular}{|c|c|c|c|c|}
\hline $\begin{array}{l}\text { Teacher has master's } \\
\text { degree }\end{array}$ & $\begin{array}{l}-.319 \\
(.019) \\
-.409 \\
(.046)\end{array}$ & $\begin{array}{l}-.319 \\
(.019) \\
\\
-.384 \\
(.049)\end{array}$ & $\begin{array}{l}-.022 \\
(.007) \\
-.421 \\
(.019)\end{array}$ & $\begin{array}{l}-.341 \\
(.021) \\
-.807 \\
(.055)\end{array}$ \\
\hline $\begin{array}{l}\text { National Board certified } \\
\text { teacher }\end{array}$ & $\begin{array}{l}-1.074 \\
(.094)\end{array}$ & $\begin{array}{l}-1.082 \\
(.094)\end{array}$ & $\begin{array}{l}-.271 \\
(.036)\end{array}$ & $\begin{array}{l}-1.353 \\
(.105)\end{array}$ \\
\hline $\begin{array}{l}\text { Graduated 'very } \\
\text { competitive' college }\end{array}$ & $\begin{array}{l}-.161 \\
(.050)\end{array}$ & $\begin{array}{l}-.158 \\
(.051)\end{array}$ & $\begin{array}{l}.014 \\
(.020)\end{array}$ & $\begin{array}{l}-.144 \\
(.058)\end{array}$ \\
\hline Middle school & $\begin{array}{l}-.404 \\
(.082)\end{array}$ & $\begin{array}{l}-.395 \\
(.082)\end{array}$ & $\begin{array}{l}.021 \\
(.032)\end{array}$ & $\begin{array}{l}-.373 \\
(.092)\end{array}$ \\
\hline High school & $\begin{array}{l}-.836 \\
(.072)\end{array}$ & $\begin{array}{l}-.798 \\
(.073)\end{array}$ & $\begin{array}{l}-.072 \\
(.028)\end{array}$ & $\begin{array}{l}-.869 \\
(.082)\end{array}$ \\
\hline $\begin{array}{l}\text { School \% free lunch } \\
\text { *elementary school }\end{array}$ & $\begin{array}{l}.303 \\
(.164)\end{array}$ & $\begin{array}{l}.331 \\
(.168)\end{array}$ & $\begin{array}{l}.287 \\
(.064)\end{array}$ & $\begin{array}{l}.621 \\
(.189)\end{array}$ \\
\hline $\begin{array}{l}\text { School } \% \text { free lunch } \\
* \text { middle school }\end{array}$ & $\begin{array}{c}.991 \\
(.234)\end{array}$ & $\begin{array}{l}1.045 \\
(.239)\end{array}$ & $\begin{array}{l}.148 \\
(.091)\end{array}$ & $\begin{array}{l}1.195 \\
(.268)\end{array}$ \\
\hline $\begin{array}{l}\text { School \% free lunch } \\
* \text { high school }\end{array}$ & $\begin{array}{l}1.599 \\
(.259)\end{array}$ & $\begin{array}{l}1.492 \\
(.265)\end{array}$ & $\begin{array}{l}.178 \\
(.101)\end{array}$ & $\begin{array}{l}1.670 \\
(.297)\end{array}$ \\
\hline District $\%$ free lunch & $\begin{array}{l}.096 \\
(.274)\end{array}$ & & & \\
\hline School \% nonwhite & $\begin{array}{l}.457 \\
(.146)\end{array}$ & $\begin{array}{l}.583 \\
(.149)\end{array}$ & $\begin{array}{l}-0.045 \\
(.057)\end{array}$ & $\begin{array}{l}.534 \\
(.167)\end{array}$ \\
\hline District $\%$ n onwhite & $\begin{array}{l}-.310 \\
(.213)\end{array}$ & & & \\
\hline $\mathrm{R}^{2}$ & .035 & .031 & .050 & .041 \\
\hline $\begin{array}{l}\text { Mean of dependent } \\
\text { variable }\end{array}$ & 8.95 & 8.95 & 11.19 & 20.14 \\
\hline
\end{tabular}

Note: Standard errors in parentheses. Other variables in regression specifications included whether other nonwhite teacher, log of ratio of teacher salary to other teacher salaries within 30 miles of district, $\log$ of teacher salary, log of ratio of teacher salary by teacher experience/salary type to non-teacher salaries for counties within 30 miles of district, whether graduated from college deemed competitive according to Barrons' ranking, county unemployment rate, and black teacher/nonwhite student percentage and other nonwhite teacher/nonwhite student percentage interaction terms. Equation 2.1 also includes the log of growth in district enrollment between 1990 and 1995 and the log of district enrollment indicators for school year along with rural district and mountain and coastal region indicators. For the full list and means of equation 2.1 variables, see Appendix Table A2. The full set of estimated coefficients corresponding to equation (2.1) is given in Appendix Table A3. Equations (2.2) to (2.4) use district-year fixed effects.

Source: North Carolina Education Research Data Center. 3/15/07 
Table 3. Average Absences per Teacher, Selected Categories, by School Income Quartile, $2000 / 01$

\begin{tabular}{rcccc}
\hline & $\begin{array}{l}\text { Lowest income } \\
\text { quartile }\end{array}$ & 2nd quartile & 3rd quartile & $\begin{array}{l}\text { Highest income } \\
\text { quartile }\end{array}$ \\
\hline Elementary Schools & & & & \\
\hline FTE teachers & 9,946 & 10,187 & 9,930 & 9,597 \\
All absences & 23.8 & 23.2 & 23.8 & 23.4 \\
Sick leave & 8.5 & 8.0 & 8.2 & 7.8 \\
Personal leave & 1.9 & 1.9 & 1.8 & 1.8 \\
Annual vacation leave & 10.7 & 10.7 & 11.3 & 11.2 \\
\hline Middle Schools & & & & \\
\hline FTE teachers & 4,439 & 4,507 & 4,512 & 4,449 \\
All absences & 23.0 & 22.1 & 22.3 & 22.3 \\
Sick leave & 8.2 & 7.8 & 7.6 & 7.3 \\
Personal leave & 1.9 & 1.6 & 1.5 & 1.5 \\
Annual vacation leave & 10.3 & 10.4 & 10.6 & 10.8 \\
\hline High Schools & & & & 1.5 \\
\hline FTE teachers & 5,827 & 5,743 & 5,744 & 5,844 \\
All absences & 22.9 & 20.4 & 21.6 & 21.3 \\
Sick leave & 7.5 & 6.6 & 6.6 & 6.5 \\
Personal leave & 1.8 & 1.5 & 1.5 & 1.5 \\
Annual Vacation leave & 10.6 & 9.8 & 11.2 & 10.8 \\
\hline Not: & & & & \\
\hline
\end{tabular}

Note: FTE is full-time equivalent. Schools are classified by quartiles of percent free lunch, where the quartile breaks are defined separately for elementary, middle, and high schools, taking all years together. Income quartiles are based on full-time equivalent teacher counts. Where data on percent free lunch were missing, data for the school in the previous year or following year were used instead, where possible. All remaining schools were dropped. The lowest income quartile refers to the schools with the highest percentage of students eligible for free lunch. For the state's schools, the $25^{\text {th }}, 50^{\text {th }}$, and $75^{\text {th }}$ percentiles for proportion free lunch were, respectively: .244, .360, and .516 in elementary schools; .204, .298, and .428 in middle schools; and .103,.169, and .268 in high schools. Absences are for 10-month year or year equivalent. $3 / 1 / 07$ 
Table 4. Prevalence of High Absence Schools, by Income Quartile, combined years, 1994/95 to $2003 / 04$

\begin{tabular}{|c|c|c|c|c|}
\hline & $\begin{array}{l}\text { Lowest income } \\
\text { quartile }\end{array}$ & 2nd quartile & 3rd quartile & $\begin{array}{l}\text { Highest income } \\
\text { quartile }\end{array}$ \\
\hline Elementary schools & 33.9 & 24.7 & 22.3 & 19.4 \\
\hline Middle schools & 25.6 & 15.4 & 10.4 & 7.8 \\
\hline High schools & 16.0 & 5.3 & 1.8 & 3.2 \\
\hline
\end{tabular}

Note: Schools are classified by quartiles of percent free lunch, where the quartile breaks are defined separately for elementary, middle, and high schools, taking all years together. See note, Table 3.

Table entries indicate the weighted percentage of schools by income quartile which were in the highest quartile of average absences, taking all years together (more than 9.84 sick + personal days per teacher), in at least five years in the period 1994/95 to 2003/04, where the weights are full-time equivalent teachers times years in the sample. A school that appears in different income quartiles over the period will be reflected according to the number of years and FTE teachers in each income quartile. Schools appearing in fewer than five years were omitted.

$3 / 7 / 07$ 
Table 5. Teacher Absences and Student Achievement. Basic Estimates and Validity Checks. (Estimated coefficients for sick plus personal days in equations explaining normalized end-ofgrade tests, grades 4-5, 1994/95-2003/04)

\begin{tabular}{|c|c|c|c|c|}
\hline & Math & Reading & Math & Reading \\
\hline & \multicolumn{2}{|c|}{ No fixed effects } & \multicolumn{2}{|c|}{ Teacher fixed effects } \\
\hline \multicolumn{5}{|l|}{$\underline{\text { Model A }}$} \\
\hline Number of days absent & $\begin{array}{c}-.0023 * * * \\
(.0001)\end{array}$ & $\begin{array}{c}-.0011 * * * \\
(.0001)\end{array}$ & $\begin{array}{c}-.0017 * * * \\
(.0001)\end{array}$ & $\begin{array}{c}-.0009 * * * \\
(.0001)\end{array}$ \\
\hline \multicolumn{5}{|l|}{ Model B } \\
\hline $\begin{array}{l}\text { Number of days absent, } \\
\text { July- December, }\end{array}$ & $\begin{array}{c}-.0010 * * * \\
(.0002)\end{array}$ & $\begin{array}{l}-.0003 * \\
(.0002)\end{array}$ & $\begin{array}{c}-.0007 * * * \\
(.0002)\end{array}$ & $\begin{array}{c}-.0004 * * \\
(.0002)\end{array}$ \\
\hline $\begin{array}{l}\text { Number of days absent, } \\
\text { January-June }\end{array}$ & $\begin{array}{c}-.0030 * * * \\
(.0002)\end{array}$ & $\begin{array}{c}-.0015^{* * *} \\
(.0001)\end{array}$ & $\begin{array}{c}-.0023 * * * \\
(.0001)\end{array}$ & $\begin{array}{c}-.0012 * * * \\
(.0001)\end{array}$ \\
\hline $\begin{array}{l}\text { Coefficients } \\
\text { significantly different? }\end{array}$ & Yes*** & Yes*** & Yes*** & Yes*** \\
\hline \multicolumn{5}{|l|}{ Model C } \\
\hline $\begin{array}{l}\text { Number of absences } \\
\text { covered by certified } \\
\text { substitute }\end{array}$ & $\begin{array}{c}-.0020 * * * \\
(.0002)\end{array}$ & $\begin{array}{c}-.0005^{* * *} * \\
(.0002)\end{array}$ & $\begin{array}{c}-.0017 * * * \\
(.0002)\end{array}$ & $\begin{array}{c}-.0006^{* * *} \\
(.0002)\end{array}$ \\
\hline $\begin{array}{l}\text { Number of absences } \\
\text { covered by noncertified } \\
\text { substitute }\end{array}$ & $\begin{array}{c}-.0025 * * * \\
(.0001)\end{array}$ & $\begin{array}{c}-.0013 * * * \\
(.0001)\end{array}$ & $\begin{array}{c}-.0018 * * * \\
(.0001)\end{array}$ & $\begin{array}{c}-.0010 * * * \\
(.0001)\end{array}$ \\
\hline $\begin{array}{l}\text { Coefficients } \\
\text { significantly different? }\end{array}$ & Yes** & Yes*** & No & Yes** \\
\hline
\end{tabular}

Note: Standard errors in parentheses. Asterisks signify significantly different from zero at the $10 \%$ level(*), $5 \%$ level(**), and $1 \% \operatorname{level}(* * *)$.

Source: North Carolina Education Research Data Center.

$3 / 20 / 07$ 
Table. 6. Teacher Absences and Student Achievement: Heterogeneity. (Estimated coefficients for sick plus personal days and interaction terms in equations explaining normalized end-of-grade tests, grades 45.)

\begin{tabular}{|c|c|c|c|c|}
\hline & $\begin{array}{l}\text { Math } \\
\text { (No fixed effects) }\end{array}$ & $\begin{array}{l}\text { Reading } \\
\text { (No fixed effects) }\end{array}$ & $\begin{array}{l}\text { Math } \\
\text { (Fixed effects) }\end{array}$ & $\begin{array}{l}\text { Reading } \\
\text { (Fixed effects) }\end{array}$ \\
\hline \multicolumn{5}{|l|}{ A. Rural district } \\
\hline Absences & $\begin{array}{l}-.00202 * * * \\
(.00014)\end{array}$ & $\begin{array}{l}-.00084 * * * \\
(.00014)\end{array}$ & $\begin{array}{l}-.00124 * * * \\
(.00014)\end{array}$ & $\begin{array}{l}-.00064 * * * \\
(.00011)\end{array}$ \\
\hline Interaction term & $\begin{array}{l}-.00062 * * * \\
(.00019)\end{array}$ & $\begin{array}{l}-.00049 * * * \\
(.00014)\end{array}$ & $\begin{array}{l}-.00104 * * * \\
(.00021)\end{array}$ & $\begin{array}{l}-.00052 * * * \\
(.00017)\end{array}$ \\
\hline \multicolumn{5}{|c|}{ B. Black/Other nonwhite student } \\
\hline Absence & $\begin{array}{l}-.00217 * * * \\
(.00013)\end{array}$ & $\begin{array}{l}-.00100 * * * \\
(.00010)\end{array}$ & $\begin{array}{l}-.00171 * * * \\
(.00011)\end{array}$ & $\begin{array}{l}-.00089 * * * \\
(.00009)\end{array}$ \\
\hline Interaction-black & $\begin{array}{l}-.00032 * \\
(.00018)\end{array}$ & $\begin{array}{l}-.00009 \\
(.00016)\end{array}$ & $\begin{array}{l}.00028 \\
(.00015)\end{array}$ & $\begin{array}{l}.00006 \\
(.00014)\end{array}$ \\
\hline $\begin{array}{l}\text { Interaction-other } \\
\text { nonwhite }\end{array}$ & $\begin{array}{l}-.00111 * * \\
(.00044)\end{array}$ & $\begin{array}{l}-.00105^{* * *} \\
(.00040)\end{array}$ & $\begin{array}{l}-.00065^{* *} \\
(.00032)\end{array}$ & $\begin{array}{l}-.00036 \\
(.00033)\end{array}$ \\
\hline \multicolumn{5}{|c|}{ C. Student receiving free lunch } \\
\hline Absences & $\begin{array}{l}-.00213 * * * \\
(.00013)\end{array}$ & $\begin{array}{l}-.00099 * * * \\
(.00010)\end{array}$ & $\begin{array}{l}-.00163^{* * *} \\
(.00012)\end{array}$ & $\begin{array}{l}-.00086^{* * *} \\
(.00010)\end{array}$ \\
\hline Interaction term & $\begin{array}{l}-.00038^{* *} \\
(.00015)\end{array}$ & $\begin{array}{l}-.00018 \\
(.00014)\end{array}$ & $\begin{array}{l}-.00022 * \\
(.00012)\end{array}$ & $\begin{array}{l}-.00006 \\
(.00013)\end{array}$ \\
\hline \multicolumn{5}{|c|}{ D. Parent without high school degree } \\
\hline Absences & $\begin{array}{l}-.00229 * * * \\
(.00012)\end{array}$ & $\begin{array}{l}-.00105 * * * \\
(.00009)\end{array}$ & $\begin{array}{l}-.00172 * * * \\
(.00011)\end{array}$ & $\begin{array}{l}-.00087 * * * \\
(.00009)\end{array}$ \\
\hline Interaction term & $\begin{array}{l}-.00022 \\
(.00027)\end{array}$ & $\begin{array}{l}-.00036 \\
(.00028)\end{array}$ & $\begin{array}{l}-.00023 \\
(.00024)\end{array}$ & $\begin{array}{l}-.00026 \\
(.00026)\end{array}$ \\
\hline \multicolumn{5}{|c|}{ E. Students with below-average test score, lagged } \\
\hline Absences & $\begin{array}{l}-.00084 * * * \\
(.00013)\end{array}$ & $\begin{array}{l}.00057 * * * \\
(.00009)\end{array}$ & $\begin{array}{l}-.00028 * * \\
(.00012)\end{array}$ & $\begin{array}{l}.00073 * * * \\
(.00010)\end{array}$ \\
\hline Interaction term & $\begin{array}{l}-.00300^{* * *} \\
(.00013)\end{array}$ & $\begin{array}{l}-.00351 * * * \\
(.00013)\end{array}$ & $\begin{array}{l}-.00301 * * * \\
(.00012)\end{array}$ & $\begin{array}{l}-.00352 * * * \\
(.00012)\end{array}$ \\
\hline
\end{tabular}


F. Teachers w/ 0-2 years experience

\begin{tabular}{lllll} 
Absences & $-.00233^{* * *}$ & $-.00112 * * *$ & $-.00178^{* * *}$ & $-.00092 * * *$ \\
& $(.00013)$ & $(.00009)$ & $(.00011)$ & $(.00009)$ \\
Interaction term & .00014 & .00039 & $.00051 *$ & -.00033 \\
& $(.00035)$ & $(.00026)$ & $(.00030)$ & $(.00026)$ \\
\hline
\end{tabular}

Note: Standard errors in parentheses. ${ }^{* * *}=\mathrm{P}<.01, * *=\mathrm{P}<.05, *=\mathrm{P}<.1$

$3 / 20 / 07$ 
Table 7. Absences and the $\$ 50$ Absence Penalty: Cox Proportional Hazard Model Estimates

\begin{tabular}{|c|c|}
\hline Variable & Hazard ratio (Standard error) \\
\hline Cost & $1.003\left(1.8 * 10^{-4}\right)$ \\
\hline \multicolumn{2}{|l|}{ Teacher characteristics } \\
\hline Male & $1.096(.008)$ \\
\hline Maternity probability & $.077(.007)$ \\
\hline Black & $.975(.012)$ \\
\hline Other non white & $1.000(.031)$ \\
\hline Age & $.988(.002)$ \\
\hline $\operatorname{Age}^{2}(x \quad 100)$ & $1.000\left(2.5 * 10^{-5}\right)$ \\
\hline \multicolumn{2}{|l|}{ Experience (0 years omitted $)$} \\
\hline 1 year & $.760(.009)$ \\
\hline $2-3$ years & $.666(.007)$ \\
\hline $4-5$ years & $.619(.007)$ \\
\hline $6-10$ years & $.602(.008)$ \\
\hline $11-30$ years & $.633(.011)$ \\
\hline Over 30 years & $.590(.012)$ \\
\hline Log of teacher salary & $.974(.035)$ \\
\hline Log of salary/a lternate teacher salary ratio & $.930(.040)$ \\
\hline Log of salary/n on-teaching teacher salary ratio & $1.203(.018)$ \\
\hline Graduated North Carolina college & $1.013(.005)$ \\
\hline Graduated college in state bordering NC & $.982(.008)$ \\
\hline Teacher test score & $1.041(.002)$ \\
\hline Teacher has master's degree & $1.052(.005)$ \\
\hline National Board certified teacher & $1.079(.011)$ \\
\hline Graduated 'very competitive' college & $1.047(.006)$ \\
\hline Graduated 'competitive' college & $1.026(.004)$ \\
\hline \multicolumn{2}{|l|}{ School characteristics (Elementary school omitted) } \\
\hline Middle school & $.988(.009)$ \\
\hline High school & $1.043(.008)$ \\
\hline
\end{tabular}


School \% free lunch * elementary school

$.999\left(1.8 * 10^{-4}\right)$

School \% free lunch * middle school

$.999\left(2.6 * 10^{-4}\right)$

School \% free lunch * high school

$.998\left(2.9 * 10^{-4}\right)$

School \% student nonw hite

$.999\left(1.6 * 10^{-4}\right)$

\section{District characteristics}

District \% free lunch

$1.000\left(2.8 * 10^{-4}\right)$

District \% no nwhite

$1.000\left(2.3 * 10^{-4}\right)$

County unem ployment rate

$.995(.001)$

Black teacher * student nonwhite percentage

$.999\left(2.1 * 10^{-4}\right)$

Other non white teacher * student nonw hite

$1.000\left(4.8 * 10^{-4}\right)$ percentage

Growth in district enrollment from previous year

$1.000(.003)$

Log of district enrollment

$.993(.003)$

District is rural

$.943(.005)$

Coastal district

$.994(.006)$

Mounta in district

$1.017(.006)$

School Year 1995 (1994/95 o mitted)

1996

$1.024(.010)$

1997

$1.016(.010)$

1998

$1.042(.010)$

1999

$1.010(.011)$

2000

$1.037(.012)$

2001

$1.009(.013)$

2002

$1.016(.014)$

2003

$.978(.014)$

2004

2005

Log likelihood

$-4,016,121.7$

LR $\operatorname{chi}^{2}(46)$

$11,619.77$

Number of Subje cts

341,420 
Appendix Table A1. Absence Codes, 2000/01 School Year

\begin{tabular}{lrrl}
\hline Code/Definition & Number & Percentage & Classification \\
\hline 01 Sick Leave, NS & 474,659 & \multicolumn{1}{l}{ (1.1 } & $\mathrm{S}$ \\
02 Voluntary Shared Leave & 1,415 & 0.1 & $\mathrm{P}$ \\
03 Extended Sick Leave, NS & 13,494 & 0.9 & $\mathrm{~S}$ \\
04 Absence without Deduction, NS & 186,445 & 12.2 & $\mathrm{~A}$ \\
05 Absence with Deduction, NS & 705 & 0.1 & $\mathrm{P}$ \\
06 Personal Leave, NS & 53,707 & 3.5 & $\mathrm{P}$ \\
07 Absence without Pay, NS & 46,868 & 3.1 & $\mathrm{P}$ \\
08 Sick Leave Bank, NS & 2 & 0.0 & $\mathrm{~S}$ \\
10 Child Involvement Leave & 642 & 0.0 & $\mathrm{P}$ \\
11 Sick Leave, CS & 62,683 & 4.1 & $\mathrm{~S}$ \\
12 Other Absence & 90 & 0.0 & $\mathrm{P}$ \\
13 Extended Sick Leave, CS & 1,633 & 0.1 & $\mathrm{~S}$ \\
14 Absence without Deduction, CS & 28,064 & 1.4 & $\mathrm{~A}$ \\
15 Absence with Deduction, CS & 172 & 0.0 & $\mathrm{P}$ \\
16 Personal Leave, CS & 9,061 & 0.6 & $\mathrm{P}$ \\
17 Absence without Pay, CS & 2,311 & 0.2 & $\mathrm{P}$ \\
18 Sick Leave Bank, CS & 1 & 0.0 & $\mathrm{~S}$ \\
20 Annual Leave & 644,166 & 42.2 & $\mathrm{~V}$ \\
22 Annual Leave for Catastrophic Illness & 98 & 0.0 & $\mathrm{~V}$ \\
28 Bonus Annual Leave & 1 & 0.0 & $\mathrm{~V}$ \\
No Code Defined & 0.0 & $\mathrm{P}$ \\
\hline NS-Non-Cerified Sus & & \\
\hline
\end{tabular}

$\mathrm{NS}=$ Non-Certified Substitute, $\mathrm{CS}=$ Certified Substitute

Notes: Observations are at the teacher, absence code and pay period level. Observations can include duplicate entries for teachers teaching in more than 1 school. Absence classification: SSick leave, P-Personal leave, $\mathrm{V}=$ Vacation (Annual) leave, $\mathrm{A}=$ Administrative leave.

$3 / 1 / 07$ 
Appendix Table A2. Means of Teacher Absence Regression Variables, Pooled Data for 1994/95 to $2003 / 04$

\begin{tabular}{|c|c|c|c|c|}
\hline Variable & Mean & Standard Dev. & Min & Max \\
\hline Male & 0.190 & 0.392 & 0 & 1 \\
\hline Black & 0.144 & 0.351 & 0 & 1 \\
\hline Other no nwhite & 0.017 & 0.130 & 0 & 1 \\
\hline Age & 38.711 & 10.708 & 20 & 72 \\
\hline Age squared & 1613.198 & 852.252 & 400 & 5184 \\
\hline Maternity probability & 0.036 & 0.044 & 0 & 0.108 \\
\hline Log of salary & 10.482 & 0.206 & 10.100 & 11.034 \\
\hline \multicolumn{5}{|l|}{ Experience (zero years omitted) } \\
\hline 1 Year & 0.048 & 0.214 & 0 & 1 \\
\hline 2-3 Years & 0.096 & 0.295 & 0 & 1 \\
\hline 4-5 Years & 0.084 & 0.277 & 0 & 1 \\
\hline $6-10$ Years & 0.168 & 0.373 & 0 & 1 \\
\hline $10-30$ Years & 0.504 & 0.500 & 0 & 1 \\
\hline Over 30 Years & 0.039 & 0.193 & 0 & 1 \\
\hline Log of Sa lary/Alternate tea cher salary ratio & 0.005 & 0.039 & -0.093 & 0.111 \\
\hline Log of Sa lary/Non-tea ching salary ratio & 0.147 & 0.233 & -0.514 & 0.783 \\
\hline Graduated North Carolina college & 0.739 & 0.439 & 0 & 1 \\
\hline Graduated college in state bordering NC & 0.054 & 0.227 & 0 & 1 \\
\hline Teacher test score & 0.041 & 0.948 & -28.194 & 3.743 \\
\hline Teacher has master's degree & 0.295 & 0.456 & 0 & 1 \\
\hline Nationally Board certified teacher & 0.038 & 0.190 & 0 & 1 \\
\hline Graduated 'very competitive' college & 0.179 & 0.383 & 0 & 1 \\
\hline Graduated 'competitive' college & 0.560 & 0.496 & 0 & 1 \\
\hline Middle school & 0.220 & 0.414 & 0 & 1 \\
\hline High school & 0.284 & 0.451 & 0 & 1 \\
\hline School $\%$ free lunch * elementary school & 0.192 & 0.240 & 0 & 0.991 \\
\hline School $\%$ free lunch $*$ middle school & 0.070 & 0.155 & 0 & 0.949 \\
\hline
\end{tabular}




\begin{tabular}{|c|c|c|c|c|}
\hline \multirow[b]{2}{*}{ School \% free lunch * high school } & \\
\hline & 0.056 & 0.118 & 0 & 0.979 \\
\hline School \% student nonw hite & 0.388 & 0.250 & 0 & 1 \\
\hline District $\%$ free lunch & 0.306 & 0.120 & 0 & 0.759 \\
\hline District \% stu dent nonw hite & 0.381 & 0.191 & 0.008 & 0.974 \\
\hline County une mployment rate & 4.936 & 2.036 & 1.2 & 18.2 \\
\hline Black teacher*student nonwhite percentage & 0.084 & 0.224 & 0 & 1 \\
\hline $\begin{array}{l}\text { Other no nwhite teacher*student non white } \\
\text { percentage }\end{array}$ & 0.010 & 0.085 & 0 & 1 \\
\hline $\begin{array}{l}\text { Growth in district enrollment from previous } \\
\text { year }\end{array}$ & 0.014 & 0.014 & -0.028 & 0.060 \\
\hline Log of district enrollment & 9.816 & 1.079 & 6.498 & 11.663 \\
\hline District is rural & 0.438 & 0.496 & 0 & 1 \\
\hline Coastal district & 0.168 & 0.374 & 0 & 1 \\
\hline Moun tain district & 0.219 & 0.413 & 0 & 1 \\
\hline \multicolumn{5}{|l|}{ School Year 1995 (1994/95 omitted) } \\
\hline 1996 & 0.086 & 0.280 & 0 & 1 \\
\hline 1997 & 0.089 & 0.284 & 0 & 1 \\
\hline 1998 & 0.091 & 0.288 & 0 & 1 \\
\hline 1999 & 0.094 & 0.292 & 0 & 1 \\
\hline 2000 & 0.096 & 0.295 & 0 & 1 \\
\hline 2001 & 0.098 & 0.297 & 0 & 1 \\
\hline 2002 & 0.097 & 0.296 & 0 & 1 \\
\hline 2003 & 0.092 & 0.289 & 0 & 1 \\
\hline 2004 & 0.092 & 0.289 & 0 & 1 \\
\hline \multicolumn{5}{|l|}{ Means of dep endent variables: } \\
\hline Sick + Pers onal Days & 8.948 & 10.839 & 0 & 150 \\
\hline Leave (Vacation) Days & 11.192 & 5.272 & 0 & 150 \\
\hline Sick + Pers onal + Vacation Days & 20.140 & 12.610 & 0 & 150 \\
\hline
\end{tabular}

Note: Standard errors in parentheses.

Source: North Carolina Education Research Data Center 3/15/07 
Appendix Table A3. Full Regression Explaining Teacher Absence due to Sickness and Personal Leave, Pooled Data for 1994/95 to 2003/04

\begin{tabular}{|c|c|}
\hline Variable & Coefficient (Standard Error) \\
\hline \multicolumn{2}{|l|}{ Teacher characteristics } \\
\hline Male & $-.716(.066)$ \\
\hline Matern ity probability & $34.348(.811)$ \\
\hline Black & $-.387(.118)$ \\
\hline Other no nwhite & $-.342(.079)$ \\
\hline Age & $.127(.019)$ \\
\hline Age squared (x 100) & $-.112(.022)$ \\
\hline \multicolumn{2}{|l|}{ Experience (zero years omitted) } \\
\hline 1 Year & $1.843(.083)$ \\
\hline 2-3 Years & $2.794(.077)$ \\
\hline 4-5 Years & $3.536(.091)$ \\
\hline $6-10$ Years & $3.472(.105)$ \\
\hline $10-30$ Years & $2.108(.140)$ \\
\hline Over 30 Years & $4.834(.187)$ \\
\hline Teacher salary & $1.499(.280)$ \\
\hline Salary/Altern ate teacher sa lary ratio & $-2.163(.615)$ \\
\hline Salary/No n-teaching sala ry ratio & $1.684(.135)$ \\
\hline Graduated North Carolina college & $-.013(.041)$ \\
\hline Graduated college in state bordering NC & $.297(.074)$ \\
\hline Teacher test score & $-.319(.019)$ \\
\hline Teacher has master's degree & $-.409(.046)$ \\
\hline Nationally Board certified teacher & $-1.074(.094)$ \\
\hline Graduated 'very competitive' college & $-.161(.050)$ \\
\hline Graduated 'competitive' college & $-.027(.039)$ \\
\hline \multicolumn{2}{|l|}{ School characteristics } \\
\hline \multicolumn{2}{|l|}{ Elementary school (omitted) } \\
\hline Middle school & $-.404(.082)$ \\
\hline
\end{tabular}




\begin{tabular}{|c|c|}
\hline High school & $-.836(.072)$ \\
\hline School \% free lunch * elementary school & $.303(.164)$ \\
\hline School $\%$ free lunch $*$ middle school & $.991(.234)$ \\
\hline School \% free lunch $*$ high school & $1.599(.259)$ \\
\hline School \% student nonw hite & $.457(.146)$ \\
\hline \multicolumn{2}{|l|}{ District characteristics } \\
\hline District $\%$ free lunch & $.096(.274)$ \\
\hline District $\%$ stu dent nonw hite & $-.310(.213)$ \\
\hline County une mployment rate & $-.026(.013)$ \\
\hline Black teacher*student nonwhite percentage & $.459(.192)$ \\
\hline Other nonwhite teacher*student nonwhite percentage & $.500(.432)$ \\
\hline Growth in district enrollment from previous year & $-8.644(1.689)$ \\
\hline Log of district enrollment & $.155(.025)$ \\
\hline District is rural & $.262(.046)$ \\
\hline Coastal district & $-.098(.054)$ \\
\hline Mountain district & $-.340(.060)$ \\
\hline \multicolumn{2}{|l|}{ School year (1995 (1994/95) omitted) } \\
\hline 1996 & $-.246(.075)$ \\
\hline 1997 & $-.184(.074)$ \\
\hline 1998 & $-.423(.074)$ \\
\hline 1999 & $-.166(.075)$ \\
\hline 2000 & $-.493(.065)$ \\
\hline 2001 & $.189(.076)$ \\
\hline 2002 & $.540(.078)$ \\
\hline 2003 & $.407(.082)$ \\
\hline 2004 & $.917(.078)$ \\
\hline $\mathrm{R}^{2}$ & .035 \\
\hline Mean of depend ent variable & 8.95 \\
\hline Number of observations & 492,112 \\
\hline
\end{tabular}

Note: Standard errors in parentheses. Source: North Carolina Education Research Data Center 4/3/07 
Appendix Table A4. Regression Estimates Explaining Normalized Achievement Test Scores, Grades 4 and 5, 1995-2004.

\begin{tabular}{|c|c|c|c|c|}
\hline & $\begin{array}{c}\text { OLS } \\
M A T H \\
\end{array}$ & $\begin{array}{c}O L S \\
R E A D I N G\end{array}$ & $\begin{array}{c}\text { Teachers FE } \\
\text { MATH }\end{array}$ & $\begin{array}{c}\text { Teachers FE } \\
\text { READING }\end{array}$ \\
\hline Equation & $3 A .1$ & $3 A .2$ & $3 A .3$ & $3 A .4$ \\
\hline Male & $\begin{array}{c}0.0098 \\
(0.0020)^{* *}\end{array}$ & $\begin{array}{c}-0.0276 \\
(-0.0021)^{* *}\end{array}$ & $\begin{array}{c}0.0110 \\
(0.0017)^{* *}\end{array}$ & $\begin{array}{c}-0.0273 \\
(0.0019)^{* *}\end{array}$ \\
\hline Black & $\begin{array}{c}-0.0815 \\
(0.0022)^{* *}\end{array}$ & $\begin{array}{c}-0.1208 \\
(0.0021)^{* *}\end{array}$ & $\begin{array}{c}-0.0951 \\
(0.0018)^{* *}\end{array}$ & $\begin{array}{c}-0.1272 \\
(0.0020)^{* *}\end{array}$ \\
\hline Hispanic & $\begin{array}{c}0.0765 \\
(0.0042)^{* *}\end{array}$ & $\begin{array}{c}0.0522 \\
(0.0041)^{* *}\end{array}$ & $\begin{array}{c}0.0578 \\
(0.0036)^{* *}\end{array}$ & $\begin{array}{c}0.0385 \\
(0.0039)^{* *}\end{array}$ \\
\hline Other race & $\begin{array}{c}0.0384 \\
(0.0040)^{* *}\end{array}$ & $\begin{array}{c}-0.0712 \\
(0.0037)^{* *}\end{array}$ & $\begin{array}{c}0.0389 \\
(0.0031)^{* *}\end{array}$ & $\begin{array}{c}-0.0080 \\
(0.0033)^{*}\end{array}$ \\
\hline Age in grade 3 & $\begin{array}{c}-0.0588 \\
(0.0014)^{* *}\end{array}$ & $\begin{array}{c}-0.0427 \\
(0.0014)^{* *}\end{array}$ & $\begin{array}{c}-0.0586 \\
(0.0012) * *\end{array}$ & $\begin{array}{c}-0.0440 \\
(0.0013)^{* *}\end{array}$ \\
\hline \multicolumn{5}{|l|}{ Parents are college graduates (omitted) } \\
\hline Parents are high school graduates & $\begin{array}{c}-0.1051 \\
(0.0013)^{* *}\end{array}$ & $\begin{array}{c}-0.1077 \\
(0.0014)^{* *}\end{array}$ & $\begin{array}{c}-0.1041 \\
(0.0013)^{* *}\end{array}$ & $\begin{array}{c}-0.1064 \\
(0.0014)^{* *}\end{array}$ \\
\hline Parents are high school dropouts & $\begin{array}{c}-0.2100 \\
(0.0028)^{* *}\end{array}$ & $\begin{array}{c}-0.2447 \\
(0.0030)^{* *}\end{array}$ & $\begin{array}{c}-0.2111 \\
(0.0026)^{* *}\end{array}$ & $\begin{array}{c}-0.2409 \\
(0.0029)^{* *}\end{array}$ \\
\hline Limited English & $\begin{array}{c}0.0120 \\
(0.0058)^{*}\end{array}$ & $\begin{array}{c}-0.0434 \\
(0.0061)^{* *}\end{array}$ & $\begin{array}{c}0.0069 \\
(0.0050)\end{array}$ & $\begin{array}{c}-0.0524 \\
(0.0057)^{* *}\end{array}$ \\
\hline Gifted & $\begin{array}{c}0.2698 \\
(0.0020)^{* *}\end{array}$ & $\begin{array}{c}0.2112 \\
(0.0017)^{* *}\end{array}$ & $\begin{array}{c}0.2748 \\
(0.0017)^{* *}\end{array}$ & $\begin{array}{c}0.2185 \\
(0.0016)^{* *}\end{array}$ \\
\hline Special needs & $\begin{array}{c}-0.1325 \\
(0.0020)^{* *}\end{array}$ & $\begin{array}{c}-0.1692 \\
(0.0022)^{* *}\end{array}$ & $\begin{array}{c}-0.1367 \\
(0.0018)^{* *}\end{array}$ & $\begin{array}{c}-0.1753 \\
(0.0021)^{* *}\end{array}$ \\
\hline Subsidized lunch & $\begin{array}{c}-0.0475 \\
(0.0013)^{* *}\end{array}$ & $\begin{array}{c}-0.0584 \\
(0.0014)^{* *}\end{array}$ & $\begin{array}{c}-0.0488 \\
(0.0012)^{* *}\end{array}$ & $\begin{array}{c}-0.0599 \\
(0.0013)^{* *}\end{array}$ \\
\hline Repeating grade & $\begin{array}{c}0.5403 \\
(0.0047)^{* *}\end{array}$ & $\begin{array}{c}0.4674 \\
(0.0048)^{* *}\end{array}$ & $\begin{array}{c}0.4503 \\
(0.0047)^{* *}\end{array}$ & $\begin{array}{c}0.3964 \\
(0.0053)^{* *}\end{array}$ \\
\hline Lagged math or reading score & $\begin{array}{c}0.7237 \\
(0.0009)^{* *}\end{array}$ & $\begin{array}{c}0.7031 \\
(0.0009)^{* *}\end{array}$ & $\begin{array}{c}0.7214 \\
(0.0008)^{* *}\end{array}$ & $\begin{array}{c}0.7001 \\
(0.0008)^{* *}\end{array}$ \\
\hline School change & $\begin{array}{c}-0.0228 \\
(0.0018)^{* *}\end{array}$ & $\begin{array}{c}-0.0153 \\
(0.0018)^{* *}\end{array}$ & $\begin{array}{c}-0.0161 \\
(0.0016)^{* *}\end{array}$ & $\begin{array}{c}-0.0108 \\
(0.0017)^{* *}\end{array}$ \\
\hline Structural school change & $\frac{-0.0464}{(0.0053)^{* *}}$ & $\frac{-0.0438}{(0.0042)^{* *}}$ & $\frac{-0.0092}{(0.0046)^{*}}$ & $\frac{-0.0077}{(0.0041)}$ \\
\hline \multicolumn{5}{|l|}{ Classroom characteristics } \\
\hline Class size & $\begin{array}{c}-0.0036 \\
(0.0003)^{* *}\end{array}$ & $\begin{array}{c}-0.0024 \\
(0.0002)^{* *}\end{array}$ & $\begin{array}{c}-0.0050 \\
(0.0003)^{* *}\end{array}$ & $\begin{array}{c}-0.0031 \\
(0.0002)^{* *}\end{array}$ \\
\hline Percent no nwhite & $\begin{array}{l}-0.0051 \\
(0.0061)\end{array}$ & $\begin{array}{c}0.0071 \\
(0.0045)\end{array}$ & $\begin{array}{l}-0.0131 \\
(0.0086)\end{array}$ & $\begin{array}{c}-0.0157 \\
(0.0074)^{*}\end{array}$ \\
\hline Percent subsidized lunch & $\begin{array}{c}-0.0383 \\
(0.0083)^{* *}\end{array}$ & $\begin{array}{c}-0.0027 \\
(0.0060)^{* *}\end{array}$ & $\begin{array}{c}-0.0516 \\
(0.0076)^{* *}\end{array}$ & $\begin{array}{c}-0.0129 \\
(0.0065)^{*}\end{array}$ \\
\hline Percent college grad (omitted) & & & & \\
\hline Percent high school graduates & $\begin{array}{c}-0.0443 \\
(0.0068)^{* *}\end{array}$ & $\begin{array}{c}-0.0303 \\
(0.0050)^{* *}\end{array}$ & $\begin{array}{c}-0.0272 \\
(0.0075)^{* *}\end{array}$ & $\begin{array}{c}-0.0182 \\
(0.0064)^{* *}\end{array}$ \\
\hline
\end{tabular}




\begin{tabular}{|c|c|c|c|c|}
\hline Percent high school d ropouts & $\begin{array}{c}0.0027 \\
(0.0148) \\
\end{array}$ & $\begin{array}{c}-0.0289 \\
(0.0110)^{* *}\end{array}$ & $\begin{array}{c}-0.0322 \\
(0.0146)^{*} \\
\end{array}$ & $\begin{array}{r}-0.0017 \\
(0.0127)\end{array}$ \\
\hline Lagged class average math score & $\begin{array}{c}0.0265 \\
(0.0035 * *)\end{array}$ & $\begin{array}{c}0.0593 \\
(0.0027)^{* *}\end{array}$ & $\begin{array}{l}-0.0322 \\
(0.0034)\end{array}$ & $\begin{array}{c}0.0178 \\
(0.0030)^{* *}\end{array}$ \\
\hline \multicolumn{5}{|l|}{ Teacher characteristics } \\
\hline Male & $\begin{array}{c}-0.0132 \\
(0.0043)^{* *}\end{array}$ & $\begin{array}{c}-0.0133 \\
(0.0031)^{* *}\end{array}$ & & \\
\hline Black & $\begin{array}{c}-0.0308 \\
(0.0036)^{* *}\end{array}$ & $\begin{array}{c}-0.0005 \\
(0.0027)\end{array}$ & & \\
\hline Hispanic & $\begin{array}{c}0.0166 \\
(0.0233)\end{array}$ & $\begin{array}{c}0.0050 \\
(0.0168)\end{array}$ & & \\
\hline Other race & $\begin{array}{c}-0.0471 \\
(0.0132)^{*}\end{array}$ & $\begin{array}{c}-0.0517 \\
(0.0099)^{* *}\end{array}$ & & \\
\hline Same race as the student & $\begin{array}{c}0.0266 \\
(0.0023)^{* *}\end{array}$ & $\begin{array}{c}0.0082 \\
(0.0020)^{* *}\end{array}$ & $\begin{array}{c}0.0114 \\
(0.0018)^{* *}\end{array}$ & $\begin{array}{c}0.0029 \\
(0.0019)\end{array}$ \\
\hline Same gender as the student & $\begin{array}{c}0.0033 \\
(0.0020) \\
\end{array}$ & $\begin{array}{c}-0.0062 \\
(0.0021)^{* *}\end{array}$ & $\begin{array}{c}0.0040 \\
(0.0017)^{*} \\
\end{array}$ & $\begin{array}{l}-0.0058 \\
(0.0019) \\
\end{array}$ \\
\hline \multicolumn{5}{|l|}{ Teach er creden tials } \\
\hline \multicolumn{5}{|l|}{ No experience (omitted) } \\
\hline $1-2$ years & $\begin{array}{c}0.0736 \\
(0.0052)^{* *}\end{array}$ & $\begin{array}{c}0.0467 \\
(0.0039)^{* *}\end{array}$ & $\begin{array}{c}0.0766 \\
(0.0043)^{* *}\end{array}$ & $\begin{array}{c}0.0463 \\
(0.0035)^{* *}\end{array}$ \\
\hline $3-5$ years & $\begin{array}{c}0.0958 \\
(0.0053)^{* *}\end{array}$ & $\begin{array}{c}0.0647 \\
(0.0039)^{* *}\end{array}$ & $\begin{array}{c}0.1092 \\
(0.0052)^{* *}\end{array}$ & $\begin{array}{c}0.0680 \\
(0.0042)^{* *}\end{array}$ \\
\hline $6-12$ years & $\begin{array}{c}0.0994 \\
(0.0052)^{* *}\end{array}$ & $\begin{array}{c}0.0743 \\
(0.0038)^{* *}\end{array}$ & $\begin{array}{c}0.1293 \\
(0.0062)^{* *}\end{array}$ & $\begin{array}{c}0.0816 \\
(0.0051)^{* *}\end{array}$ \\
\hline $13-20$ years & $\begin{array}{c}0.0978 \\
(0.0053)^{* *}\end{array}$ & $\begin{array}{c}0.0796 \\
(0.0039)^{* *}\end{array}$ & $\begin{array}{c}0.1493 \\
(0.0076)^{* *}\end{array}$ & $\begin{array}{c}0.0992 \\
(0.0062) * *\end{array}$ \\
\hline 21-27 years & $\begin{array}{c}0.1119 \\
(0.0054)^{* *}\end{array}$ & $\begin{array}{c}0.0886 \\
(0.0039)^{* *}\end{array}$ & $\begin{array}{c}0.1554 \\
(0.0088)^{* *}\end{array}$ & $\begin{array}{c}0.1076 \\
(0.0073)^{* *}\end{array}$ \\
\hline $28+$ years & $\begin{array}{c}0.1073 \\
(0.0061)^{* *}\end{array}$ & $\begin{array}{c}0.0913 \\
(0.0044)^{* *}\end{array}$ & $\begin{array}{c}0.1548 \\
(0.0099)^{* *}\end{array}$ & $\begin{array}{c}0.1157 \\
(0.0083)^{* *}\end{array}$ \\
\hline \multicolumn{5}{|l|}{ Regular license (omitted) } \\
\hline Lateral entry & $\begin{array}{l}-0.0188 \\
(0.0227)\end{array}$ & $\begin{array}{c}0.0365 \\
(0.0170)^{*}\end{array}$ & & \\
\hline |Interact continuing/lateral entry & $\begin{array}{c}-0.0144 \\
(0.0180)\end{array}$ & $\begin{array}{l}-0.0186 \\
(0.0137)\end{array}$ & & \\
\hline Other license & $\begin{array}{c}-0.0382 \\
(0.0050)^{* *}\end{array}$ & $\begin{array}{c}-0.0150 \\
(0.0038)^{* *}\end{array}$ & & \\
\hline Master's degree & $\begin{array}{c}-0.0049 \\
(0.0025)^{*}\end{array}$ & $\begin{array}{c}-0.0010 \\
(0.0018)^{* *}\end{array}$ & & \\
\hline National Board Certified & $\begin{array}{c}0.0356 \\
(0.0143)^{*}\end{array}$ & $\begin{array}{c}0.0278 \\
(0.0100)^{*}\end{array}$ & $\begin{array}{c}0.0472 \\
(0.0161)^{* *}\end{array}$ & $\begin{array}{c}0.0450 \\
(0.0141)^{* *}\end{array}$ \\
\hline \multicolumn{5}{|c|}{ Undergraduate college non-competitive (omitted) } \\
\hline Competitive & $\begin{array}{c}0.0086 \\
(0.0027)^{* *}\end{array}$ & $\begin{array}{l}-0.0004 \\
(0.0020)\end{array}$ & & \\
\hline Very competitive & $\begin{array}{c}0.0125 \\
(0.0037)^{* *}\end{array}$ & $\begin{array}{c}0.0050 \\
(0.0027)\end{array}$ & & \\
\hline
\end{tabular}




\begin{tabular}{|c|c|c|c|c|}
\hline Unranked & -0.0120 & -0.0142 & & \\
\hline & $(0.0074)$ & $(0.0052)^{* *}$ & & \\
\hline Mean teacher test score & 0.0123 & 0.0070 & & \\
\hline & $(0.0014)^{* *}$ & $(0.0010)^{* *}$ & & \\
\hline Absences & & & & \\
\hline Number of sick + personal days & -0.0024 & -0.0011 & -0.0017 & -0.0009 \\
\hline & $(0.0001)^{* *}$ & $(0.0001)^{* *}$ & $(0.0001)^{* *}$ & $(0.0001)^{* *}$ \\
\hline Constant & 0.6731 & 0.5568 & 0.6811 & 0.5712 \\
\hline & $(0.0161)^{* *}$ & $(0.0146)^{* *}$ & $(0.0149)^{* *}$ & $(0.0144)^{* *}$ \\
\hline Number of Observations & 997,408 & $1,005,380$ & $1,123,603$ & $1,131,781$ \\
\hline R-Squared & 0.7200 & 0.6924 & 0.7551 & 0.7063 \\
\hline
\end{tabular}

Note: Stan dard erro rs are shown in parenthese s. Depen dent variab le is normalize d achievem ent test score on North Carolina end-of-grade tests. *significant at 5\% level; **significant at $1 \%$ level.

$3 / 15 / 07$ 